\title{
A Path to a Sustainable Trawl Fishery in Southeast Asia
}

Suuronen, Petri; Pitcher, C. Roland; McConnaughey, Robert A.; Kaiser, Michel; Hiddink, Jan Geert; Hilborn, Ray

\section{Reviews in Fisheries Science \& Aquaculture}

\author{
DOI: \\ $10.1080 / 23308249.2020 .1767036$
}

Published: 01/10/2020

Peer reviewed version

Cyswllt i'r cyhoeddiad / Link to publication

Dyfyniad o'r fersiwn a gyhoeddwyd / Citation for published version (APA):

Suuronen, P., Pitcher, C. R., McConnaughey, R. A., Kaiser, M., Hiddink, J. G., \& Hilborn, R. (2020). A Path to a Sustainable Trawl Fishery in Southeast Asia. Reviews in Fisheries Science \& Aquaculture, 28(4), 499-517. https://doi.org/10.1080/23308249.2020.1767036

\footnotetext{
Hawliau Cyffredinol / General rights

Copyright and moral rights for the publications made accessible in the public portal are retained by the authors and/or other copyright owners and it is a condition of accessing publications that users recognise and abide by the legal requirements associated with these rights.

- Users may download and print one copy of any publication from the public portal for the purpose of private study or research.

- You may not further distribute the material or use it for any profit-making activity or commercial gain

- You may freely distribute the URL identifying the publication in the public portal ?
}

Take down policy

If you believe that this document breaches copyright please contact us providing details, and we will remove access to the work immediately and investigate your claim. 


\title{
A path to a sustainable trawl fishery in Southeast Asia
}

\author{
Petri Suuronen ${ }^{1 *}$, C. Roland Pitcher ${ }^{2}$, Robert A. McConnaughey ${ }^{3}$, Michel J. Kaiser ${ }^{4}$, Jan G. Hiddink ${ }^{5}$, \\ Ray Hilborn ${ }^{6}$
}

\footnotetext{
${ }^{1}$ Natural Resources Institute Finland, Helsinki, Finland

${ }^{2}$ CSIRO Oceans \& Atmosphere, Queensland Biosciences Precinct, Australia

${ }^{3}$ Alaska Fisheries Science Center, National Marine Fisheries Service, NOAA, Seattle, WA, USA

${ }^{4}$ The Lyell Centre, Institute of Life and Earth Sciences, Heriot-Watt University, Edinburgh, UK

${ }^{5}$ School of Ocean Sciences, Bangor University, Anglesey, UK

${ }^{6}$ University of Washington, Seattle, WA, USA
}

Petri Suuronen https://orcid.org/0000-0001-7743-4091

C. Roland Pitcher https://orcid.org/0000-0003-2075-4347

Robert A. McConnaughey https://orcid.org/0000-0002-8537-3695

Michel J. Kaiser https://orcid.org/0000-0001-8782-3621

Jan G. Hiddink https://orcid.org/0000-0001-7114-830X

\begin{abstract}
Trawl fishing constitutes an important part of the marine fisheries sector in Southeast Asia. It provides livelihoods and food for millions of people in coastal communities as well as feed for the region's growing aquaculture sector. Trawl fisheries suffer from a multitude of problems, including overcapacity, excessive fishing effort, poor profitability and inadequate governance. The historical decline in catch per unit of effort, increasing proportion of low-value fish in trawl catches, widespread illegal fishing, and user conflicts reflect the weak management of these fisheries. Various measures implemented in the region have been insufficient to achieve sustainable outcomes. There has been little incentive for fishers to satisfactorily comply with the regulations. To understand better what kind of approaches would be effective and workable, the specific characteristics of SE Asian trawl fisheries are described and the fundamental barriers that must be addressed to improve sustainability and social benefits are identified. Meeting these challenges needs consideration of the socio-economic insecurity and the lack of alternative livelihoods as well as the complex ecological, cultural and institutional characteristics in the region. Simple, robust, equitable and easily enforced management measures are likely to work best in such a challenging environment. Properly implemented co-management systems would help to create incentives for individuals to cooperate. Trust building, participatory approaches, strong leadership and capacity building are important components to move SE Asian fisheries towards sustainability targets.
\end{abstract}

Keywords: trawling, management, barriers, solutions, incentives, leadership

*Corresponding author: Petri.Suuronen@luke.fi 


\section{Introduction}

The production of marine capture fisheries in Southeast Asia has continued to increase during the last five decades, although recently at a slower rate than in 1960s-1990s (FAO 2018). Currently, six SE Asian countries (Indonesia, Malaysia, Myanmar, Philippines, Thailand and Vietnam) contribute c. $18 \%$ of the world's reported marine fisheries landings (FAO 2018). A large proportion of the increase in the fishery production in the region has been attributed to the expansion of trawl fishing (Butcher 2004; FungeSmith et al. 2012). Trawling began to expand in the mid-1960s and since then has played an important role in the region's food supply and livelihoods and has provided much needed income and foreignexchange earnings (FAO 2014).

There is general agreement that a vast majority of nearshore demersal fisheries resources in the SE Asian region are overexploited (Christensen 1998; Abu Talib et al. 2003; Silvestre et al. 2003; Sugiyama et al. 2004; Pomeroy 2012; Khatib 2015). Since the early 1970s there has been a general declining trend in the catch per unit effort (CPUE) particularly for the most valuable species in demersal trawl fishing (Kongprom et al. 2003; Stobutzki et al. 2006a; DOF 2015; Anon. 2016a). Furthermore, species composition in demersal trawl catches has changed over time with an increasing proportion of smallsized low-value fish (Butcher 2004; Garces et al. 2006a; Stobutzki et al. 2006b; Siar et al. 2017), reflecting changes in demersal fish communities. These declining indicators have fuelled arguments that intensive trawling has had a detrimental effect on fisheries resources and marine ecosystems in the region (Butcher 2004; Pomeroy et al. 2016). Nevertheless, coastal fisheries resources also are intensively exploited by many other metiers, and hence contribute to over-exploitation (Butcher 2004).

The profitability of trawl fishing has declined over time due to decreasing catches of valuable species and increasing costs of fishing (Ahmed et al. 2007; FAO 2014; Siar et al. 2017). The trawl-fishing sector has attempted to compensate for the reduction of revenues by increasingly targeting large volumes of small-sized low-value species, known in SE Asia as "trash fish" (Funge-Smith et al. 2005; Nguyen 2017). Low-value fish are used mainly as the base ingredient for feed in the growing aquaculture sector, either directly, or through reduction to fish meal and oil. These fish also provide a source of cheap food for domestic markets and are important for the poorest people (Funge-Smith et al. 2012). Low-value fish have become an important, if not crucial, part of income and revenues in demersal trawling. Development of new seafood products, such as surimi, has created additional demand for the fish raw materials although in surimi production the quality requirements of fish are higher than in the feed production.

The rapidly increasing demand for food and aquaculture feed in SE Asia has placed considerable pressure on the region's coastal fisheries resources. Some progress has been made recently in the management of the fisheries in the region, but resources are still largely exploited without effective limits on the amount of fishing that takes place (Pomeroy 2012; DOF 2015; Derrick et al. 2017). To date, attempts at regulating and controlling coastal fishing have been ineffective and volatile. Governments have insufficient enforcement and surveillance capacity, and often there is a lack of consensus among key stakeholders about which management actions would be effective. Short-term employment and livelihood-maintenance strategies have a dominant influence. Weak stakeholder participation and serious user conflicts characterize many of these fisheries (Salayo et al. 2006; Pomeroy 2012). Furthermore, across the SE Asian region, large numbers of fishermen have resorted to illegal practices to compensate for reduced catches, which in turn has further reduced the size of already dwindling populations of the most valuable demersal species (FAO 2007). There is an urgent need to develop and implement strategies that will help to ensure long-term sustainable fishing in the region.

During the last three decades, several studies, initiatives and projects have explored the problems and suggested management solutions for SE Asian fisheries (e.g. SEAFDEC 2003; Silvestre et al. 2003; FAO 2014). Some countries (e.g. Thailand and Malaysia) have developed fisheries management plans (Anon. 
2015; Anon. 2016a; DOF 2015) and have implemented these to the best of their abilities. The resources of central and local bodies, however, are highly inadequate for managing the fisheries they govern, and sustainability is rarely promoted and enforced in any substantive way (Pomeroy et al. 2010, 2016; FAO 2007, 2014; Nguyen 2017). Nonetheless, without the actions taken so far, the current fisheries management situation would likely be worse.

The present study deals with trawl fishing, which is the most important and most challenging type of fishing to manage in SE Asia (Gillet 2008). There are relatively few reliable statistics of the characteristics and volume of trawl fishing in SE Asia against which to assess the fishing pressure. There is little reliable documentation of the current catches, effort, viability and other key indicators of the trawl fleets. This study seeks to address these knowledge gaps and provide an information base of the status and complexities in the SE Asian trawl fisheries to better understand the fundamental motives and barriers that have to be addressed to improve trawl fisheries management and guide transition to more effective management practices in the region. Information for this study has been collected from various official and unofficial sources, primary and grey literature, as well as from stakeholder consultations and other outputs of various projects that have been conducted in the region, such as the FAO-GEF REBYC-II CTI project (http://www.rebyc-cti.org/) that was operational in 2011-2017 (Suuronen et al. 2013; Anon. 2016b; Siar et al. 2017).

The study describes the critical barriers in SE Asian trawl fisheries and provides guidance on best management practices. The focus is on the crucial question of how to make a positive change in the management of these heavily exploited multispecies fisheries. The study considered six SE Asian countries (Indonesia, Malaysia, Myanmar, Philippines, Thailand, and Vietnam) where trawl fishing has a significant role in the marine fisheries economy. With the potential exception of Malaysia, these countries have scored poorly in complying with the FAO Code of Conduct for Responsible Fisheries (Pitcher et al. 2009).

\section{Characteristics of trawl fisheries in SE Asia}

\subsection{Trawler fleets}

The trawling sector in SE Asia is diverse and covers a wide range of vessel sizes, from small-scale outrigger canoes powered by 10-15 hp engines up to industrial-scale trawlers with up to $1700 \mathrm{hp}$ engines (Butcher 2004; Aye and Win 2013; Duto et al. 2013; Nuruddin and Isa 2013; Nguyen 2017). Most of the older trawlers are relatively small, less than 10 Gross Tonnage (GT) and <150 hp, are typically made of wood and are poorly equipped. These vessels have a limited range and fishing capacity. Over time, however, there has been a trend towards bigger and better equipped trawlers with an average length around 14-18 m, engine size of 150-400 hp, and tonnage of around 10-50 GT or more. A substantial number of newer trawlers have a steel hull with engine size $>400 \mathrm{hp}$. The fishing capacity of the vessels has increased due to the introduction of bigger engines, more powerful winches and better fishing gear designs, as well as wider use of electronic aids, navigation technologies and acoustic instruments for gathering information on fish disposition on fishing grounds (Butcher 2004; Gillet 2008; FAO 2014; Siar et al. 2017). Large vessels can fish in the deeper offshore waters and use larger gears, and may therefore have a higher catch rate. Nonetheless, the larger size has not necessarily made the trawlers economically more viable than the smaller trawlers (Siar et al. 2017).

Most of the trawlers in SE Asia are otter trawlers targeting demersal finfish and shrimp. In some countries, such as Vietnam, pair trawling is common, and a proportion of these pair trawlers target small pelagic species such as anchovy. The total average number of trawlers in the six countries during the period 2010-2015 was estimated at 47500 vessels (Table 1). The overall number of effective trawling units, however, was about 40000 because a portion of these trawlers conduct pair trawling (twotrawlers per unit). Approximately 15000 of these trawlers are small-scale $(<5 \mathrm{GT})$. 
The yearly number of active trawlers is highly variable in each SE Asian country and the official numbers of trawlers reported in general are an underestimate (Nguyen and Thi 2010; Purwanto 2010; Teh and Teh 2014; DOF 2015; Pauly and Budimartono 2015; Teh et al. 2015; Derrick et al. 2017; Jumnongsong 2017; Ramiscal et al. 2017; CEA 2018). Typically, a large proportion of the vessels are not registered or do not have an official licence and in general do not appear in the official statistics. Moreover, vessels are often converted to another type of fishing when legislative conditions change. It is also worth noting that the number of vessels tells little of the overall fishing capacity of a fleet. The size and engine power of the vessels is a key measure. For instance, a $<14 \mathrm{~m}$ Thai trawler in the Gulf of Thailand in late 2000s typically caught 10-30 kg/hour, whereas a medium size of trawler (14-18 m; Fig. 1) caught 40-100 $\mathrm{kg} /$ hour (Supongpan and Boonchuwong 2010). Annex 1 provides more information of the development of trawler fleets in SE Asia.

\subsection{Trawl operation}

Apart from the Arafura Sea industrial fishery, demersal trawling in the region largely occurs in nearshore coastal waters (frequently $<30 \mathrm{~nm}$ from the coast) and has a marked overlap and interaction with fisheries using other gears such as gillnets (Garces et al. 2006b; Pho 2007; Garces and Silvestre 2010). In some SE Asian countries, such as Vietnam, there has been a tendency for trawling activities to occur further offshore (Nguyen 2017).

Demersal trawlers in SE Asia operate at depths ranging between $10 \mathrm{~m}$ and $100 \mathrm{~m}$ but are often restricted to a maximum depth of about $70 \mathrm{~m}$ or less because of poor technical capacity of vessels (Butcher 2004; FAO 2014). Smaller trawlers are able to trawl only in very shallow waters, often 5-30 m, where the number of species and the proportion of small-sized fish are usually higher than in deeper waters (Butcher 2004; Pho 2007). Bottom trawls in SE Asia are towed mainly on muddy seabeds but also on mixed mud, clay and sand bottoms, and occasionally also on more sensitive grounds such as seagrass beds. There is little scientific information of the potential impacts on seabed habitats and biota caused by bottom trawling in SE Asia but apparently trawling has had impacts, and especially on shallow water sea grass beds (Kongprom et al. 2003; Noranarttragoon and Phoonsawat 2012; Khemakorn 2014).

Trawl tow-times are typically 2-4 hours but as CPUE has decreased over time, fishers have tended to use longer tow durations of up to 8 hours (Siar et al. 2017). This trend is linked to an expanding capture of low-value fish used for the preparation of feed in the aquaculture sector where quality demands are not as strict as with the human food sector. It is common practice in many SE Asian countries that much of the catch is landed in plastic bags packed with some ice. Only the most valuable part of the catch is properly stored and cooled with ice. The spoilage of catch is common. Annex 2 provides more details of trawl operations.

\subsection{Harvesting pattern and bycatch in trawl fishing}

Trawl codend mesh size (stretched full mesh) in SE Asia is typically only $15-35 \mathrm{~mm}$, and usually somewhat less in shrimp trawling than in mixed finfish-shrimp trawling. In essence, the trawl fishing in SE Asia is non-selective, resulting in large volumes of juvenile fish, small-sized fish species and other organisms in the catches, especially when trawlers operate in shallow waters (Funge-Smith et al. 2005; Eayrs et al. 2007; Siar et al. 2017). Discarding is uncommon except for the Arafura Sea industrial shrimp fishery (Perez Roda et al. 2019). Nonetheless, special "Juvenile and Trashfish Excluder Devices" (JTEDs) are utilized in the Samar Sea in the Philippines by the larger trawlers in order to have cleaner shrimp catches (Ramiscal et al. 2017). Furthermore, the capture of endangered, threatened or protected species such as rays, sharks and sea turtles is a cause of concern in SE Asian trawl fisheries but few management actions have been taken to mitigate these incidental catches (Gillet 2008; FAO 2014). In the Arafura Sea industrial shrimp trawl fishery, the use of a Turtle Excluder Device (TED) has been compulsory since 1982 but there is no evidence that they are properly implemented (Af-idati and Lee 
2009). In Vietnam, the capture of sea turtles and marine mammals is rare and trawl fishers normally release them alive at sea (Nguyen 2017).

\subsection{Trawl fishing effort}

Except for Malaysia and Thailand, there is little reliable information of the total fishing effort of trawl fishing in SE Asian countries. With the available data, only very rough estimates can be made of the overall effort. Typically, trawlers fish year-round with some brief breaks during the year for vessel maintenance (Siar et al. 2017). Fishers tend to maximize the fishing time at sea. Some countries (such as Malaysia and Myanmar) have closed seasons when trawlers are not allowed to operate. For mediumsize trawlers it is common practice to stay at sea for 2-4 days, whereas larger vessels may remain at sea up to 10 days or more per trip. Anecdotal evidence suggests that vessels are staying at sea longer, travelling further and fishing deeper waters because of diminishing catch rates (Gillet 2008; Nguyen 2017).

In Malaysia, trawl fishing effort is recorded by the Department of Fisheries as the total number of trawl tows per year. In 2012 there were c. 5.8 million trawl tows (Annual Fisheries Statistics, Malaysia). If an average trawl tow is three hours in duration, the total trawling effort was c. 17.4 million hours. Dividing this by 6028 trawlers (see Table 1), the average yearly towing time per boat would have been 2887 hours in 2012. The annual number of towing hours will vary considerably between vessels and year.

In the Gulf of Thailand (in 2010), the total fishing effort of the c. 2860 active Thai demersal trawlers (or demersal pair trawling units) was c. 10 million hours (Noranarttragoon 2014). Hence, the average towing time per unit would have been c. 3500 hours. For comparison, in 1990 the overall nominal fishing effort of Thai demersal trawlers in the Gulf of Thailand was assessed as 15.4 million hours with a fleet almost three times larger than in 2010 (Ahmed et al. 2007). During the period 1990-2010, the overall trawling effort in the Gulf of Thailand declined by $30 \%$ while the fleet size declined by $60 \%$. This indicates that a reduction of fleet size did not lead to a corresponding reduction in the overall fishing effort. There is no effort information available for the Thai trawling fleet in the Andaman Sea (Indian Ocean); it represents c. $30 \%$ of the whole Thai trawler fleet.

\subsection{Trawl landings}

Demersal trawling in SE Asia is a complex multi-species fishery. Approximately 300 species of teleosts, elasmobranchs, crustaceans, molluscs, and echinoderms frequently contribute to the landings (Butcher 2004). The species composition of the catch depends on a wide variety of factors such as the location of the trawling activity, time of the year, the design and rigging of the gear, towing speed, and seabed depth and type. Although shrimp is important in terms of economic value, targeted shrimp trawling has become less common than in the 1960s and 1970s. This is mainly because of the poor profitability of shrimp fishing due to declining catch per unit of effort (CPUE) of shrimp catches and the growth of shrimp aquaculture. In the targeted shrimp fishery, the proportion of shrimp is usually $10-15 \%$ of the total catch (Siar et al. 2017) and is typical for many tropical shrimp fisheries (Gillet 2008).

Assessing the country-level trawl landings in the region is not an easy task. The available statistics are often contradictory, unclear and difficult to interpret. Only Indonesia and Malaysia provide official country-level trawl landings data. For the other countries, we must use the landings data reported to the FAO. However, these data are not partitioned by gear type. Therefore, we applied country-level knowledge of the share of the total marine landings taken by trawl gears (Aye and Win 2013; Duto et al. 2013; Nguyen and Thi 2010; FAO 2014; DOF 2015; Siar et al. 2017) to the total marine landings reported to the FAO by these countries. We estimated that in 2010-2016 trawl fisheries in the six countries landed yearly on average c. 3.6 million tonnes of fish, shellfish and squid, representing $23.4 \%$ of all marine landings for those countries (Table 2). 
The contribution of trawl fishing to the total catch varies significantly among the countries. In Malaysia, Thailand and Vietnam trawl fishing provided $37-45 \%$ of all marine landings whereas in the other three countries it provided $10-20 \%$ of the marine landings. Due to inadequate data, it is generally not possible to separate how much of the total trawl landings are from otter-board and pair trawling. Nonetheless, in 2007 in the Gulf of Thailand trawl fishery, otter-board trawling constituted $80 \%$ of the total trawl catch with $20 \%$ associated with pair trawling (Supongpan and Boonchuwong 2010). The data do not allow trawl catches to be split between demersal and pelagic species. Nonetheless, the share of small pelagic species is likely to be high in Vietnam where the use of high-opening pair trawls is common.

Country-level catch statistics reported to the FAO indicate the landings by species groups, such as shrimps. Although a part of tropical shrimp landings is from various types of gillnet fisheries, the major portion of tropical shrimp is caught by trawl (Gillet 2008). The overall shrimp landings reported to FAO likely give the best available estimate of their shrimp landings in trawl fisheries of the six countries included in this study (Table 2). The average annual shrimp landings in 2010-2016 was 623943 tonnes, which was $17.4 \%$ of the total estimated annual trawl landings in the six countries of this study. These six countries provided about $47 \%$ of the total world-wide tropical shrimp landings in $2010-2016$.

It must be emphasized that the catch reporting systems in SE Asian countries has high uncertainty and the catch statistics at best give only a rough indication of the actual catches. In many countries, the vessels do not maintain regular and accurate log-books of their catches (e.g. Nguyen 2017). In a highly multi-species fishery it is a major challenge for the skipper to accomplish a detailed species-specific catch report. Port-sampling occurs in larger fishing harbours but catch quantity and composition are usually only roughly estimated. A significant amount of landings are reported to FAO as "marine fishes not identified" or "miscellaneous fishes". Nonetheless, because shrimp is an important export product in all SE Asian countries, shrimp catch statistics tend to be more accurate than the statistic of catches used in domestic markets.

\subsection{Status of fisheries resources and trawl CPUE}

The status of fisheries resources in SE Asia is poorly known due to a lack of appropriate monitoring data and stock assessments. Most studies are outdated, and available data are often unreliable indicators of the current status. Species-specific CPUE data from fishery-independent trawl surveys are currently the best available measure of the status of demersal fishery resources. In the Gulf of Thailand, the state of demersal fishery resources has been monitored continuously since the early 1960s with trawl surveys (Joompol 2010; Khemakorn 2014; DOF 2015). All major target fish groups show a decrease in abundance and biomass. The average CPUE of the survey trawl was $100-300 \mathrm{~kg} / \mathrm{h}$ in the $1960 \mathrm{~s}$ and $50-100 \mathrm{~kg}$ in the 1970s. In 2010-2013 the average CPUE had dropped to $12-15 \mathrm{~kg} / \mathrm{h}$ (DOF 2015). It is not clear how well the yearly trawl surveys have been standardized and whether they have systematically included all the small-sized low-value species that currently compose the major part of commercial trawl catches. Furthermore, the codend mesh size in the survey trawl may have been larger than what is currently used in the commercial trawls (see Stobutzki et al. 2006b), perhaps resulting in a negative bias for smaller individuals or species.

There are arguments suggesting that the effective removal of larger and longer-lived predatory species has allowed a higher biomass of small, shorter-lived, fast-recruiting and low-value species (Gillet 2008; Pomeroy et al. 2016; Szuwalski et al. 2017). This apparently has contributed to the maintenance of trawl catches in SE Asia at a level where intensive exploitation remains profitable. In fact, the trends in commercial Thai trawl catch rates in the Gulf of Thailand do not show a dramatic decline (Ahmed et al. 2007; DOF 2015; Siar et al. 2017). It is important to take into account the significant increase in vessel fishing power over the last decades. Current vessels produce a markedly higher CPUE than did vessels two-three decades ago. 
In Malaysia the number of trawlers increased rapidly in the 1970s and commercial catch rates declined gradually thereafter (Nuruddin and Isa 2013; Teh and Teh 2014). On the east coast of the Malay Peninsula, average catch rates of commercial trawlers fell from $520 \mathrm{~kg} / \mathrm{h}$ to $160 \mathrm{~kg} / \mathrm{h}$ between 1970 and 1981 , while in the northern part of the Straits of Malacca, catch rates fell from $130 \mathrm{~kg} / \mathrm{h}$ to $55 \mathrm{~kg} / \mathrm{h}$ during the same period (Nuruddin and Isa 2013). Teh and Teh (2014) estimated that average catch rates for trawlers of c. $100 \mathrm{hp}$ declined between the $1970 \mathrm{~s}$ and late $1990 \mathrm{~s}$ from $30-40 \mathrm{~kg} / \mathrm{h}$ to $23 \mathrm{~kg} / \mathrm{h}$. For larger trawlers they estimated the decline was from $200 \mathrm{~kg} / \mathrm{h}$ to less than $100 \mathrm{~kg} / \mathrm{h}$. More recent data are not available, but by using the overall number of trawling hours and the trawl catches estimated is this study, we can roughly calculate that the average CPUE of trawlers in Malaysia in 2012 was c. 38 $\mathrm{kg} / \mathrm{h}$.

Studies undertaken by the Research Institute for Marine Fisheries (RIMF) indicate that in Vietnam there has been a marked decline in commercial trawl catch rates during the last two decades (Nguyen and Thi 2010; Nguyen 2011; Nguyen 2017). In Myanmar, the average annual total catch per trawler fell from 300 tonnes in the 1970s to 90 tonnes in 2006-2007 (Aye and Win 2013).

\section{Key barriers and potential solutions}

Trawl fisheries in SE Asia are subject to management measures that typically include license regulations, gear prohibitions, and spatial and time restrictions, but these measures have been insufficient to achieve sustainable outcomes (Pomeroy 2012; FAO 2014; DOF 2015). There are few regulations that limit the total fishing effort or the total trawl catch. Catch limits have been applied only in the Arafura Sea industrial shrimp trawl fishery. Trawl fisheries in SE Asia suffer from a multitude of interlinked problems, including overcapacity, excessive fishing effort, illegal fishing, and poor governance (Stobutzki et al. 2006a; Ahmed et al. 2007; Pomeroy 2012; Carbonetti et al. 2014). The following sections provide insights into the challenges that frame future potential solutions. Table $\mathbf{3}$ summarizes the key barriers to and guidance for improvements in the sustainable management of these fisheries.

\section{Fleet overcapacity}

Fleet overcapacity is one of the leading causes of overfishing in SE Asia (Stobutzki et al. 2006a; Pomeroy et al. 2016). License restriction is the most common approach in the region to control the size of the fleets. In Malaysia and Thailand, recently there has been progress in fleet reduction by restricting the number of fishing licenses by area (Nuruddin and Isa 2013; Anon. 2015; DOF 2015). Nonetheless, registration systems are incomplete, and many countries have experienced difficulties in preventing new entries into their fisheries and (e.g. Ahmed et al. 2007). Furthermore, even if the size of the fleet could be reduced, fish stocks would remain a common resource available to the remaining fishing vessels, which could become incentivized to fish more. In addition, maintaining the fishing power within target range would require a constant reduction of the fleet size because the technical capacity of existing vessels improves continually. This is a major challenge in SE Asian countries.

Reduction of fleet size means that a proportion of fishers would need to find new fishing opportunities or other livelihoods. In SE Asia, there are few realistic alternative livelihoods for fishers and vessel owners who are excluded from a fishery. They often do not have the education and/or skills required to enable them to participate in other livelihoods. Alternative livelihood activities may also be less profitable than fishing. Hence, displaced fishers may continue fishing by illegal means. Alternative livelihoods should be offered in the fields that give realistic opportunities for success and for which (given training and support) fishers have the necessary skills. These fields could include fish processing and trade, aquaculture, coastal tourism, habitat restoration, manufacturing of artificial reefs, and monitoring services supporting fisheries management. Alternative livelihoods could also be supplementary and allow some level of fishing for displaced fishers. 
It is worth noting that there are no effective vessel buy-back programs in SE Asia, which is partly due to their expense (Willmann et al. 2003), but also because buy-back programs would not be effective in an open-access system. Notwithstanding the problems, an effective freezing of the number of trawlers and stricter control in the construction of new trawlers in all SE Asian countries would be an important first step in taking control of fleet sizes (see also McConnaughey et al. 2020).

\section{Excessive fishing effort}

Trawl fisheries in SE Asia suffer from excessive fishing effort suffer from excessive fishing effort, which is closely linked to fleet overcapacity. Most countries in the region have various types of plans to reduce effort. For instance, the Thai Fisheries Management Plan has an objective to reduce fishing effort by $40 \%$ for demersal species in the Gulf of Thailand (DOF 2015). The reduction of effort will be achieved by allowing only a certain number of fishing days per month for each trawler. It remains to be seen how this regulation will be enforced and what will be the outcome.

Establishing a system of "total allowable days at sea" could be an appropriate step in all SE Asian countries, although fishing grounds close to ports may become more heavily exploited. It is important that there are regulations in place that prevent the compression of trawling activity into coastal areas where there is potentially greater overlap with habitats and species of conservation concern. In addition, potentially irregular landings may pose problems for processors that require continuous supply of product. The initial setting of appropriate number of allowed days at sea might be difficult but the system would allow adaptive learning. The great benefit of days-at-sea management is that it is relatively easy and robust to control. Vessels can be seen and recorded when they remain in port and they can be monitored remotely using satellite monitoring devices (if available) when they are at sea. The costs of keeping vessels tied-up for several days per month may not be feasible for all vessel owners (unless the CPUE increases markedly). Hence, only the most efficient vessels may be able to maintain adequate profitability and continue the fishing.

Effort-control schemes are vulnerable to technological creep (Eigaard et al. 2014) and expansion of other fisheries on the fishing grounds while trawl fishing is reduced (McConnaughey et al. 2020). A major challenge in SE Asia is also the extensive geographical area and large number of fishing harbors spread over the entire coastline and thousands of islands. The number of officials and patrol boats to control the fisheries is inadequate in the region. Enforcement would need a strong participation from the fishing sector (self-enforcing). In addition, various types of fuel-subsidies in many SE Asian countries have exacerbated the high levels of fishing effort and contribute to the persistence of inefficient operations. These subsidy systems should be reformed or removed (Sumaila et al. 2016). Funds that currently are utilized for fuel subsidies could be redirected into development of alternative livelihoods and value-added fish processing, as well as to improvement of fisheries management.

\section{Poor profitability}

Poor profitability of trawl fishing is both caused by and contributing to excessive fishing effort. It is caused largely by the poor status of demersal fisheries resources (low CPUE) and by the low value of species making up the catches but is also due to the characteristically high operational cost of fishing (e.g. DOF 2015; Eayrs et al. 2017). Fuel often comprises $60-75 \%$ of the operational costs for trawl fishing in SE Asia (Eayrs et al. 2017; Siar et al. 2017). The long-term solution to increase the profitability in SE Asia would be to allow a recovery of fisheries resources and then exploit these stocks sustainably with an optimal fleet size and effort level. Such an approach would increase the CPUE and the profitability for those vessels that remain within the fishery and would reduce the amount of time spent at sea, thereby minimising secondary ecosystem effects of fishing on the wider ecosystem. Nonetheless, when profitability is poor and there is no social security system, fishers have few realistic possibilities to comply with management schemes that would restrict their current fishing effort, catch and hence income. 
Increasing the value of the catch would increase the profitability, but could also attract more fishing effort. At present, product quality is negatively affected by inadequate catch handling and storage practices associated with trawlers in SE Asia. Especially the smaller trawlers routinely experience 20-40 $\%$ spoilage of catch because of a lack of proper cold storage (e.g. Siar et al. 2017), and hence a major share of the catches is marketed as low value product for the feed and fish meal industry. Shorter tows, shorter trips, and better catch handling and storage practices would help to improve quality and price, and to reduce fuel costs. Intensive training, technology transfer, and investment would be crucial to develop higher-value products from fisheries resources. Reducing the direct costs of fishing offers further possibilities to increase the profitability. Cruising at slower speeds, ensuring that the hulls are regularly cleaned, and using optimal gear design and rigging would all lead to substantial decreases in fuel consumption and would increase profitability (Eayrs et al. 2017). Nonetheless, all attempts to improve profitability must include measures to control overall fishing effort.

\section{Inadequate zoning}

Coastal zoning is a widely used measure in SE Asia to prevent conflicts between the trawling sector and small-scale inshore fishers, and to reduce the ecosystem impact of trawl fishing. Nonetheless, zoning is seldom established based on scientific criteria (Garces et al. 2006a; Garces and Silvestre 2010); the distance to the shore is the most common criterion. Identification of coastal areas that are most vulnerable to demersal trawl fisheries is a fundamental task in developing effective zoning system. Furthermore, zones are often poorly enforced, and trawlers frequently enter shallow fishing grounds allocated to small-scale fisheries (FAO 2014). Use of modern satellite-based vessel monitoring systems, with a strict requirement to keep it turned on, and clear visual marking of vessels, would help to ensure that trawlers do not enter closed areas. Furthermore, because smartphones are widespread among fishers, some fisheries have been able to incorporate geofencing into the mobile app so that vessels are automatically notified when they enter protected area or exclusive fishing zones (Fujita et al. 2018; USAID Oceans 2020). These type of low-cost tracking technologies would be helpful in SE Asia where fishers do not necessarily know when they enter a protected zone.

Closures established in high-CPUE areas are often strongly resisted by fishers. In many cases the only way to keep trawlers out of such areas is the use of physical anti-trawling barriers placed on the seabed. These barriers could act also as artificial reefs that contribute to the rebuilding of fishery stocks and ecosystem services. In Malaysia, monitoring conducted in part by fishers has been crucial for the control of illegal fishing in the trawl free zones.

A measure related to zoning, yet untested in SE Asia, is to establish specific "allocated trawling areas" where only trawl fishing is allowed (FAO 2014). Such an approach acknowledges the importance of fishing for local livelihoods, but also acts to encourage fishers to fish in grounds that are known to yield the best catches and thereby discourages 'prospecting' that leads to an expansion of trawl footprint. It is worth noting that in South Africa specific trawling areas in the hake fishery have been tested with promising results (Norman and Japp 2019).

\section{Extensive illegal fishing}

There is strong competition for fisheries resources in SE Asia and the whole region suffers from extensive illegal fishing. Illegal fishing occurs region-wide, with violators ranging from local small-scale fishermen to large-scale trawlers (FAO 2007; Nuruddin and Isa 2013; DOF 2015). Most of the violations are due to the encroachment of trawlers into nearshore fishing zone. Illegal activities cause serious problems for managing fisheries and lead to significant conflicts with those fishers who are operating according to regulations and report their catches. The motivation to abide by regulations dramatically decreases among all fishers when illegal activities are common on the fishing grounds. Illegal fishing is largely a consequence of overcapacity and ineffective surveillance, but it is also linked to the poverty, insecurity and corruption in the region. Reducing illegal fishing requires strong management policies and effective monitoring, control and surveillance, including VMS and unannounced inspections at sea. It also requires 
capacity building and training, use of new surveillance approaches such as drone-technologies and other new technologies (USAID Oceans 2020), and better collaboration. It may potentially require also the refusal of the fish market to buy illegally caught fish and strengthening the role of ecolabelling. The existing regional instruments and action plans to combat illegal fishing (e.g. FAO 2007) should be enforced, and synergistic national and local action plans need to be developed.

\section{Poor harvesting pattern}

There have been demands in SE Asia to reduce the extensive capture of juvenile fish in trawl fishing (FAO 2014; DOF 2015; Siar et al. 2017). Codend mesh size regulations have not been effectively enforced in the region and attempts to increase mesh size have resulted in protests by trawl fishers (Butcher 2004). The effective mesh size has remained small, often in the range of 15-25 mm. There is little incentive for fishers to conduct selective fishing because markets are readily available for all fish biomass. The fishing industry should adopt mesh sizes that would optimise the harvesting pattern, allowing juvenile fish to grow. Because the growth rate of young fish in tropical waters is high, a better size-composition in fish populations could be achieved relatively quickly given suitable effort controls. Voluntary uptake of larger mesh size, however, is unlikely when there are no immediate financial benefits. Therefore, the mesh size regulations should be effectively enforced. Unexpected at-sea boarding's would constitute effective enforcement and would also help to reduce other types of illegal fishing activities and modern slavery onboard trawlers. Nonetheless, the increase of codend mesh size would likely not be enough to change the situation in highly multi-species fisheries. To reduce effectively the capture of juvenile fish, multiple measures are needed, including the avoidance of areas of high density of juveniles and shallow water nursery grounds (FAO 2005). An additional option is to develop positive business drivers linked to high catch quality and value instead of poor-quality bulk landings. The ultimate solution would be to reduce the demand for fish in aquaculture feed and fishmeal production by developing and utilizing alternative sources of protein.

\section{Lack of trust and co-management}

One of the main concerns in SE Asia is the lack of confidence among fishers regarding the rationality, consistency and functionality of fisheries regulations, and doubt over whether other fishers will abide by regulations (Pomeroy et al. 2016). When there is no trust, there is little incentive for fishers to comply with regulations. Compliance with the regulations is realized when fishers have confidence that the change will bring them positive results within a reasonable timescale. This confidence is often missing in SE Asia. Trust can be built only when the fishers are convinced that every actor in a fishery will follow the rules. This requires fair distribution of costs and benefits, participation, leadership, transparent communication, effective measures to eliminate illegal actions, and adequate incentives. Strengthening the role of local fisher associations would be important to ensure better communication of shared objectives.

Various types of co-management arrangements have been recognized as a potential solution in SE Asia (Pomeroy 1995, 2012). A well-planned co-management plan can be empowering and practical for the appropriate scale of operation. Effective arrangements involving joint development of management measures by fishers, government, local communities and fish byers have emerged for instance in the Philippines (Anon. 2016a; Ramiscal et al. 2017) but are not yet widely utilized in SE Asia. Regional pilot programs should be implemented to demonstrate the usefulness of co-management arrangements in trawl fisheries. Implementing effective co-management often requires considerable input from the government, including training and capacity building to fishers' organizations (Pomeroy 2012; Ramiscal et al. 2017). Once a necessary capacity is built, governments can play a supportive rather than a directive or managerial role.

\section{Lack of user-rights}

Rights-based approaches are a commonly advocated solution for creating incentives for fishers to fish in a sustainable manner (Charles 2002; Grafton et al. 2006; Hilborn 2007). These approaches attempt to 
create a sense of ownership of fisheries resources. In SE Asia user-rights systems are not well tested. One major obstacle is the large number of different types of fisheries and vessels targeting the same resources. The highly multispecies nature of fisheries in the region further compounds the underlying complexity (Alam et al. 2002; Squires et al. 2003). The fact that user-rights are generally assigned to fishers based on their catch histories may cause substantial problems because historical catch and/or sales data are often non-existent in SE Asian fisheries (Ahmed et al. 2007). Another issue is the high proportion of nomadic fishers from other communities who would likely not be part of the same userrights system. This would complicate any application of user rights.

There is a need to develop and test user-right approaches that would be suitable to SE Asian conditions. Group fishing rights and territorial use rights for fishing, known as TURFs, provide a defined group of users with a clearly defined area and the group of users regulate themselves to promote a cooperative behaviour (Gelcich et al. 2012). TURFs require a collective group understanding of the value of the rights and the capability to co-manage the resources (Pomeroy 2012). The group must have the ability to limit access (e.g. from entities outside the group), which may be a major problem in SE Asia. More experience is needed to assess the feasibility of TURFs in SE Asia, and hence the experimental trial of TURFs would be a sensible first step in this region.

\section{Lack of scientific knowledge}

Stock status is one of the critical parameters used in the implementation of management plans and measures to assess the sustainability of fisheries and fisheries resources (Branch et al. 2011). In SE Asia most fisheries and species are not covered by any form of assessment. This has severely impeded the ability of coastal authorities to make informed decisions on sustainable and responsible fishing practices. There is also a significant lack of science-based knowledge about the region's marine ecosystems to inform policies that would lead to the establishment of sound models for integrated coastal management. Further, scientific capacity in fisheries management is diminishing in many countries of the region (FAO 2014), in contrast to the urgent need for an increase in scientific monitoring of fisheries resources in the region (APFIC/FAO 2012). Fishers should be part of the monitoring process and fisheries log-book systems should be strengthened through innovative new technologies such as remote electronic monitoring and catch analysis (Suuronen and Gilman 2020; USAID Oceans 2020). Nonetheless, it is important to acknowledge that the basic problems in fisheries do not lie in adequate science; they lie in human needs and human behaviour (Cochrane 2008).

\section{Inadequate regulatory frameworks and lack of political will}

The centralized top-down approach in SE Asian fisheries management focuses largely on formulation of regulations that aim to maintain employment and production, reduce conflicts between different fishing sectors, and adapt to natural disasters. There is a general political reluctance in the region to make hard management decisions that would jeopardize the day-to-day livelihood and income of fishing families. Furthermore, institutional structures are often deficient and management actions are characterized by lack of coherence, consistency and clarity. There is an unsustainable mismatch between declining stock status and growing fishery production targets for many SE Asian countries. Improving the horizontal collaboration among various policy makers, agencies and local managers is fundamental to improve this situation.

\section{Discussion and conclusions}

A range of barriers that impact the development of sustainable trawl fishing in the region were identified in this study. Many of these barriers occur simultaneously, often with complex interactions. Some of them affect all fishing sectors while others are closely linked to the trawl fisheries alone, in all cases with varying degrees of importance. So far, there have been few attempts in SE Asia to prioritize and address the barriers holistically. Instead, problems are often dealt with one-by-one as they arise. No single measure, however, can achieve the full spectrum of actions needed (see also McConnaughey et 
al. 2020). A suitable package of integrated actions is required to improve sustainability and rebuild the depleted fish populations. This process requires the involvement of the whole fishing sector and will only be effective if there is a genuine desire by all key stakeholders to achieve the objectives.

Complicated and data-intensive management approaches (such as species-specific catch quotas) are currently not attainable for SE Asian fisheries. Instead, management solutions need to be robust and flexible, and suitable for the highly multispecies and multiuser context with poor fisheries data. Different intensities of management are possible and encourage simpler approaches when capacity and knowledge is insufficient (Cochrane et al. 2011). The key management actions in SE Asia are to (i) reduce excessive fleet size and overall fishing effort by areas for instance by a system of total allowable days at sea, (ii) establish and enforce effective coastal zoning and appropriate seasons closed to trawling, (iii) eliminate the uncontrolled entry of new fishers and vessels into fishing grounds, and (iv) reduce the capture of juvenile fish and post-harvest losses. The success of these actions depends on the ability of the system to enforce them, and to obtain the acceptance and compliance of stakeholders.

There has been insufficient incentive for SE Asian trawl fishers to alter their practices and satisfactorily comply with the regulations. More emphasis must be placed on their motivation and capacity for cooperation (see also Grafton et al. 2006; Cochrane 2008; Gutíerrez et al. 2011; Eayrs and Pol 2018). The current top-down management does not create motivation. There is a need for management systems that would meet the conservation objectives with as little loss of economic benefit as possible. It is important to acknowledge here that rational science-based arguments alone may have no marked impacts (Pomeroy 2012; Eayrs et al. 2014; Eayrs and Pol 2018). Building faith in a better future achieved by improved management is fundamentally important and should have a high priority.

Fishers, their associations, and other key stakeholders should play a markedly more active role in the management and monitoring of the fisheries. Co-management approaches that allow for a high level of community self-determination are increasingly seen as an appropriate pathway towards sustainability. Properly implemented co-management systems would help to create incentives for individuals to comply with rules (Gutíerrez et al. 2011; Allison et al. 2012). The Ecosystem Approach to Fisheries Management (EAFM) provides a process that could be utilized to include stakeholders in the comanagement arrangements (Staples and Funge-Smith 2009; Pomeroy et al. 2010, 2015). At the same time the access to fishery resources in SE Asia should be rationalized. A rights-based system that allocates fishing rights to a larger community group should be developed and tested in the areas and fisheries where the chances of success are reasonably good.

Regulatory frameworks should clearly specify the requirements, rights, and responsibilities placed on users to meet the goals. Once the management system is developed and enforced, it is important to keep the stakeholders informed about how the fishery is performing and whether it is achieving the objectives that have been set and whether the management system requires adjustments. In SE Asia, the challenge is to establish adequate indicators for the highly multispecies fisheries (FAO 2014; Leadbitter, 2016). Landings data collection requires substantial improvements.

Furthermore, as long as illegal fishing is largely unchecked on the fishing grounds, there is little hope for improved management and restored fish stocks (see also Pomeroy 2012). The current system with poor fisheries surveillance effectively rewards illegal operators. License and surveillance systems need to be improved significantly, and fleet sizes need to be matched to the available fish resources. Governments need to invest more resources and training in the at-sea monitoring and the fishing sector should be harnessed for the self-regulation. The applicability of new and robust electronic monitoring technologies should be tested.

There is a growing public opinion in SE Asia that bottom trawling is a destructive fishing practice and must be banned (e.g. Loh and Jaafar, 2015). Nonetheless, if properly managed, trawling can continue to 
be a significant source of food and economic benefit for the region's coastal communities. There are good examples of well-managed tropical trawl fishing from other regions such as the Northern Prawn Fishery in Australia (Macfadyen et al. 2013). The elimination of trawling would dramatically reduce the supply of fish in the domestic market in SE Asia and would also reduce the supply of raw material for fishmeal plants and aquaculture feed plants with potentially serious socio-economic consequences. Moreover, trawling is often the most practical way to economically catch shrimp and many other demersal species in industrial quantities (Suuronen et al. 2012). Ultimately, none of the benefits are realisable if trawl fishing in SE Asia does not become a collaborative and sustainable undertaking.

Clearly, SE Asian trawl fisheries are difficult and complex to manage. Nonetheless, complexity should not be abused by any interest group to avoid responsibility (Cochrane 2000). The complexity can be braked into tractable bundles and effective solutions developed for each component. The management system in the region requires comprehensive multisectoral policy coordination and effective co-management arrangements. Approaches should consider the complex cultural and institutional characteristics of the region, and the capabilities of the relevant management authorities. Governments should take a longterm view and invest in the capacity building and demonstrate the benefits of management actions and feasibility of shoreside employment based on sustainable fishery production. Governments should promote training, demonstration projects and application of new technology among their agencies for conducting effective enforcement and control. Governments should ensure that key stakeholders have a proper understanding of how, why and for whom the fishery is managed. Management actions should be designed with input from key stakeholders. Any pathway toward sustainability must also cover the human slavery issue in the region.

Lastly, the improvement in sustainable use of natural resources in general takes place in parallel with development in other key societal aspects such as education and health care (Morgan and Staples 2006; Cochrane 2008; Melnychuk et al. 2017). Hence, the process will take time and it is unrealistic to expect quick changes. It is also important to acknowledge that management of trawl fishing in isolation will not enable sustainable nearshore fisheries in the region; all key fisheries must be managed if conflict and unintended consequences are to be avoided.

\section{Acknowledgements}

The authors thank Kevern Cochrane, Simon Funge-Smith, Derek Staples, Len Garces, Steve Eayrs and Mike Pol for the enlightening and inspiring discussions regarding various aspects of SE Asian trawl fisheries. We are also grateful for the Food and Agriculture Organization of the United Nations (FAO) and Southeast Asian Fisheries Development Center (SEAFDEC) for proving information for this study. The scientific results and conclusions, as well as any views or opinions expressed herein, are those of the authors and do not necessarily reflect those of NOAA or the Department of Commerce.

\section{Data availability statement}

Data sharing is not applicable to this article as no new data were created in this study. 


\section{List of references}

Abu Talib, A., Mazalina, A. and Mohammad Faisal, M.S. 2003. Overview of Fisheries in Malaysia. Malaysian Fisheries Journal 12: 44-76. (2003)

Af-idati, N. and Lee, S.-G. 2009. Management measures of shrimp trawling fishery in Arafura Sea, Indonesia: a challenge. Journal of Coastal Development 12: 56-63.

Ahmed, M., Boonchuwongse, P., Dechboon, W. and Squires, D. 2007. Overfishing in the Gulf of Thailand: Policy challenges and bioeconomic analysis. Environmental and Development Economic 12: 145-172.

Alam, F., Ishak, O. and Squires, D. 2002. Sustainable fisheries development in the tropics: Trawlers and license limitation in Malaysia. Applied Economics 34: 325-337.

Allison, E.H., Ratner, B.D., Åsgård, B., Willmann, R., Pomerey, R. and Kurien, J. 2012. Rights-based fisheries governance: from fishing rights to human rights. Fish and Fisheries 13: 14-29.

Anon. 2010. Indonesia National Report on Bycatch Management and Reduction of Discards. REBYC-II CTI project. 27 p. www.rebyc-cti.org

Anon. 2015. National Plan of Action for the Management of Fishing Capacity in Malaysia. Plan 2. Department of Fisheries Malaysia, Purajaya. ISBN 978-967-0633-07-7. 46 p. www.dof.gov.my/NPOA.pdf

Anon. 2016a. The Samar Sea fisheries management plan. Strategies for trawl fisheries bycatch management (REBYC-II CTI) project. 37 p. www.rebyc-cti.org/.../288-the-samar-sea-fisheries-management-plan

Anon. 2016b. Report of the REBYC-II CTI regional meeting on the Future of Trawl Fisheries Management in South East Asia. 22-25 September 2016, Bangkok, Thailand. www.rebyc-cti.org

Armada, N.B. 2004. State of the demersal fisheries. pp. 42-46. In: DA-BFAR, 2004. Turbulent seas: The status of Philippine marine fisheries. Coastal Resource Management Project, Cebu City, the Philippines. 378 p.

Aye, K.M and Win, K.K. 2013. Trawl Fishery Management in Myanmar. Paper presented at APFIC/FAO Regional Expert Workshop on "Regional guidelines for the management of tropical trawl fisheries in Asia". Phuket, Thailand, 30 September-4 October 2013.

Bailey, C. 1997. Lessons from Indonesia's 1980 trawler ban. Marine Policy 21: 225-235.

https://doi.org/10.1016/S0308-597X(97)00003-1

Branch, T.A., Jensen, O.P., Ricard, D., Ye, Y., and Hilborn, R. 2011. Contrasting global trends in marine fishery status obtained from catches and from stock assessments. Conserv Biol. 25: 777-786. doi: 10.1111/j.15231739.2011.01687.x.

Butcher, J. G. 2004. The Closing of the Frontier: A History of the marine fisheries of Southeast Asia c. 18502000. Institute of Southeast Asian Studies (ISEAS), Singapore, 442 pp.

Carbonetti, B., Pomeroy, R. and Richards, D.L. 2014. Overcoming the lack of political will in small scale fisheries. Marine Policy 44: 295-301. DOI: 10.1016/j.marpol.2013.09.020

CEA 2018. Trends in Marine Resources and Fisheries Management in Indonesia. A 2018 Review. California Environmental Associates. 145 pp.

Charles, A.T. 2002. Use rights and responsible fisheries: limiting access and harvesting through rights-based management. Pp 131-158. In: A Fishery Manager's Guidebook. Management Measures and their Application (K. Cochrane, Ed.). FAO Fisheries Tech. Paper Paper Nr 424. Food and Agriculture Organization. Rome.

Chong, K-C., Dwiponggo, A., llyas, S. \& Martosubroto, P. 1987. Some experiences and highlights of the Indonesian trawl ban: Bioeconomics and socioeconomics. In Proceedings of the $22^{\text {nd }}$ Session of Indo-Pacific Fisheries Commission, Darwin, Australia, 16-26 February 1987. pp. 458-477. RAPA Report 1987/8. Bangkok. Available at http://www.fao.org/3/a-bm749e.pdf.

Christensen, V. 1998. Fishery-induced changes in a marine ecosystem: insight from models of the Gulf of Thailand. J. Fish Biol. 53 (Suppl. A): 128-142.

Cochrane, K. 2000. Reconciling sustainability, economic efficiency and equity in fisheries: the one that got away. Fish and Fisheries 1: 3-21. 
Cochrane, K. 2008. What should we care about when attempting to reconcile fisheries with conservation? American Fisheries Society Symposium 49: 5-24.

Cochrane, K.L., Andrew, N.L and Parma, A.M. 2011. Primary fisheries management: a minimum requirement for provision of sustainable human benefits in small-scale fisheries. Fish and Fisheries 12: 275-288.

Derrick, B., Noranarttragoon, P., Zeller, D., Teh, L.C.L. and Pauly, D. 2017. Thailand's Missing Marine Fisheries Catch (1950-2014). Frontiers in Marine Science 4: 402. Doi: 10.3389/fmars.2017.00402

DOF 2015. Marine Fisheries Management Plan of Thailand - A National Policy for Marine Fisheries Management 2015-2019. Department of Fisheries (DOF). Ministry of Agriculture and Cooperatives. Thailand. 89 pp.

Duto, N., Damianus, S. and Mahiswara. 2013. A brief note of trawl fisheries in Indonesia. Paper presented at APFIC/FAO Regional Expert Workshop on "Regional guidelines for the management of tropical trawl fisheries in Asia". Phuket, Thailand, 30 September-4 October 2013.

http://www.fao.org/fileadmin/templates/rap/files/meetings/2013/130930-12-brief.pdf

Eayrs, S. and Pol, M. 2018. The myth of voluntary uptake of proven fishing gear: investigations into the challenges inspiring change in fisheries. ICES Journal of Marine Science. doi:10.1093/icesjms/fsy17

Eayrs, S., Hai, N.P., and Ley, J. 2007. Assessment of juvenile and trash excluder device in a Vietnamese shrimp trawl fishery. ICES Journal of Marine Science 64: 1598-1602.

Eayrs, S., Cadrin, S.X., and Glass, C.W. 2014. Managing change in fisheries: a missing key to fishery-dependent data collection. ICES Journal of Marine Science. Doi: 10.1093/icejms/fsu184

Eayrs, S. Wanchana, W., and Suuronen, P. 2017. Fishing vessel energy audit pilot project to audit commercial shrimp trawlers in Thailand. Phase I. FAO Fisheries and Aquaculture Circular. FIAO/C1099 (En). 67 pp.

Eigaard, O. R., Marchal, P., Gislason, H., and Rijnsdorp, A.D., 2014. Technological Development and Fisheries Management. Reviews in Fisheries Science \& Aquaculture 22: 156-174. https://doi.org/10.1080/23308249.2014.899557

Endroyono, 2017. Overview of the trawl fisheries socio-economic conditions in Indonesia after the second trawl ban. Pp. 3 - 37. In: Socio-economics of trawl fisheries in Southeast Asia and Papua New Guinea (Siar, S. V., P. Suuronen, and R. Gregory, Eds.). FAO Fisheries and Aquaculture Proceedings No. 50. Rome, FAO.

FAO 2005. APFIC Regional workshop on low value and "trash fish" in the Asia-Pacific region, Hanoi, Vietnam 7-9 June 2005. FAO Regional Office for Asia and the Pacific, Bangkok, Thailand. RAP Publication 2005/21, 32 p.

FAO 2012. APFIC/FAO Regional consultative workshop: Strengthening assessment of fisheries and aquaculture in the Asia-Pacific region for policy development, Yangon, Myanmar, 4-6 October 2011. FAO Regional Office for Asia and the Pacific, Bangkok, Thailand. RAP Publication 2012/12. 50 pp.

FAO 2014. APFIC/FAO Regional Expert Workshop on "Regional guidelines for the management of tropical trawl fisheries in Asia". Phuket, Thailand, 30 September-4 October 2013. FAO Regional Office for Asia and the Pacific, Bangkok, Thailand. RAP Publication 2014/01, 91 pp.

FAO 2017. APFIC Regional Consultative Workshop on "Managing fishing capacity and IUU fishing in the Asian region". Phuket, Thailand 13-15 June 2007. FAO Regional Office for Asia and the Pacific, Bangkok, Thailand. RAP Publication 20007/18, 46 pp.

FAO 2018. The State of World Fisheries and Aquaculture 2018 - Meeting the sustainable development goals. Rome. $210 \mathrm{p}$.

Fujita, R., Cusack, C., Karasik, R., Takade-Heumacher, H. and Baker, C. 2018. Technologies for Improving Fisheries Monitoring. Environmental Defense Fund, San Francisco. $71 \mathrm{p}$.

Funge-Smith, S., Lindebo, E. and Staples, D. 2005. Asian fisheries today: The production and use of low value/trash fish from marine fisheries in the Asia-Pacific region. FAO Regional Office for Asia and the Pacific. RAP Publication 2005/16, $38 \mathrm{p}$.

Funge-Smith, S., Briggs, M. and Miao, W. 2012. Regional overview of fisheries and aquaculture in Asia and the Pacific 2012. Asia-Pacific Fishery Commission, FAO Regional Office for Asia and the Pacific. RAP Publication 2012/26. 139 pp. http://www.fao.org/docrep/017/i3185e/i3185e00.pdf 
Garces, L.R. and Silvestre, G.T. 2010. An evaluation of resource overlaps among fishing gear in the coastal fisheries using multivariate techniques. Journal of the Marine Biological Association of India 52: 1-7.

Garces L. R., Silvestre, G.T., Stobutzki, I, Gayanilo Jr., F.C, Valdez, F., Saupi, M., Boonvanich, T., Roongratri, M., Thouc, P., Purwanto, Haroon, I., Kurup, K.N., Srinath, M., Rodrigo, H.A.B., Santos, M.D., Torres Jr, F.S.B., Tan, M.K. and Pauly, D. 2006a. A regional database management system - the fisheries resource information system and tools (FiRST): Its design, utility and future directions. Fish. Res. 78: 119-129.

Garces L. R., Syobutzki, I., Alias, M., Campos, W., Koongchai, N., Lachica-Alino, L., Mustafa, G., Nurhakim, S., Srinath, M. and Silvestre, G. 2006b. Spatial structure of demersal fish assemblages in South and Southeast Asia and implication for fisheries management. Fish Res. 78: 147-157.

Gelcich, S., Fernandez, M., Godoy, N., Canepa, A., Prado, I. \& Castilla, J.C. 2012. Territorial User Rights for Fisheries as Ancillary Instruments for Marine Coastal Conservation in Chile. Conservation Biology, DOI: 10.1111/j.15231739.2012.01928.x

Gillet, R. 2008. Global study of shrimp fisheries. FAO Fisheries Technical Paper 475. Rome, FAO. 331 p.

Grafton, R.Q., R. Arnason, T. Bjørndal, D. Campbell, H. F. Campbell, C. W. Clark, R. Connor, D. P. Dupont, R. Hannesson, R. Hilborn, J. E. Kirkley, T. Kompas, D. E. Lane, G. R. Munro, S. Pascoe, D. Squires, S. I. Steinshamn, B. R. Turris, and Q. Weninger 2006. Incentive-based approaches to sustainable fisheries. Can J. Fish. Aquat. Sci. 63: 699710.

Gutíerrez, N.L., Hilborn, R. and Defeo, O. 2011. Leadership, social capital and incentives promote successful fisheries. Nature 470: 386-389. Doi:10.1038/nature09689

Hilborn, R. 2007. Defining success in fisheries and conflicts in objectives. Marine Policy 31: 153-158.

Joompol, S. 2010. Management of Demersal Resources in the Gulf of Thailand. Thai Fisheries Cazette 63(2).

Jumnongson, S. 2017. Socio-economic status of trawl fishers in Prachuap Khiri Khan - Chumphon Provinces and fishers in Trat Province, Thailand. Pp. 119 - 165. In: Socio-economics of trawl fisheries in Southeast Asia and Papua New Guinea (Siar, S. V., P. Suuronen, and R. Gregory, Eds.). FAO Fisheries and Aquaculture Proceedings No. 50. Rome, FAO.

Khatib, M.A.B.M. 2015. A mini review of the present status of the Marine Fisheries in Sabah, Malaysia. Journal of Aquaculture and Marine Biology 2 (4). DOI: 10.15406/jamb.2015.02.00033

Khemakorn, P. 2014. Trawl fishing and impacts in Thailand. Paper presented at the meeting of the Trawling Best Practice working groip, Bangkok, 11-13 September 2014.

Kongprom, A., Khaemakorn, P., Eiamsa-ard, M. and Supongpan, M. 2003. Status of demersal fishery resources in the Guld of Thailand. Pp. 137-152. In: Assessment, management and future directions for coastal fisheries in Asian Countries (G. Silvestre, L. Garces, I. Stobutzki, M. Ahmed, R.A. Valmonte-Santos, C. Luna, L. Lachia-Aliño, P. Munro, V. Christensen and D. Pauly, Eds.). WorldFish Center Conference Proceedings 67, 1120 p.

Leadbitter, D. 2016. International workshop on aspects of management planning for tropical trawl fisheries in South East Asia. NOAA US and IFFO RS, 5-7 April 2016, Bangkok, Thailand.

Loh, T.-L. and Jaafar, Z. 2015. Turning the tide on bottom trawling. Aquatic Conservation: Marine and Freshwater Ecosystems, Doi: 10.1002/aqc.2563

Macfadyen, G., Banks, R., and Davies, R. 2013. Tropical shrimp trawling: Developing a management blueprint and adapting and implementing it in specific countries and fisheries. Marine Policy 40: 25-33.

McConnaughey, R.A., Hiddink, J.G., Jennings, S., Pitcher, C.R., Kaiser, M.J., Suuronen, P., Sciberras, M., Rijnsdorp, A.D., Collie, J.S., Mazor, T., Amoroso, R., Parma, A.M., and Hilborn, R. 2020. Choosing best practices for managing the impacts of trawl fishing gears on seabed habitats and biota. Fish and Fisheries 21: 319-337. https://doi.org/10.1111/faf.12431

Morgan, G.R. and Staples, D.J. 2006. The history of industrial marine fisheries in Southeast Asia. RAP Publication 2006/12. Food and Agriculture Organization of the United Nations Regional Office for Asia and the Pacific, Bangkok, 2006.

Melnychuk, M. C., Peterson, E., Elliott, M. and Hilborn, R. 2017. Fisheries management impacts on target species status. Proceedings of the National Academy of Sciences 114, 178-183. doi.org/10.1073/pnas.1609915114 
800 Nagalaksana, C. 1987. Thailand country experience. Paper presented at the 1987 IPFC Technical Symposium "Exploitation \& management of the marine fishery resources in SE Asia".

Nguyen, T. V. 2011. Sustainable Management of Shrimp Trawl Fishery in Tonkin Gulf, Vietnam. Applied Economics Journal, Kasetsart University, Faculty of Economics, Center for Applied Economic Research, vol. 18(2): 65-81.

804

Nguyen, B. T. 2013. Catch and bycatch in the below $90 \mathrm{CV}$ shrimp trawlers in Ha Thien, Kien Giang - Case study in 2010. Paper presented at the APFIC Regional Expert Workshop on Tropical Trawl Fishery Management, 30th September - 4th October 2013, Phuket, Thailand.

Nguyen, B.T. 2017. Study on trawl fishery socio-economics and supply chains in Kien Giang, Viet Nam. Pp. $175-$ 237. In: Socio-economics of trawl fisheries in Southeast Asia and Papua New Guinea (Siar, S. V., P. Suuronen, and R. Gregory, Eds.). FAO Fisheries and Aquaculture Proceedings No. 50. Rome, FAO.

Nguyen, T.B. and Thi, D.V. 2010. Vietnam National Report on bycatch management and reduction of discards. Prepared for the REBYC-II CTI Project, 43 pp. Available at: http://www.rebyc-cti.org/

Noranarttragoon, P. 2014. Review of the Trawl Fisheries in Prachuap Khiri Khan and Chumphon Province, Thailand. REBYC-II CTI Project; GCP/RAS/269/GFF. 23 p. http://www.rebyc-cti.org/

Noranarttragoon, P. and Phoonsawat, R. 2012. Impact of mobile gear fisheries on the sea floor. Catching marine bottom fauna in the Gulf of Thailand: Fishermen or Ploughmen. Paper presented at the $6^{\text {th }}$ World Fisheries Congress, 7-11 May 2012, Edinburgh, Scotland.

Norman, S. and Japp, D. 2019. Status and Management of South African hake. Oceana Sustainability Report 2019.

Nuruddin, A. A. and Isa, M. S. 2013. Trawl fisheries in Malaysia - issues, challenges and mitigating measures. Paper presented at the APFIC Regional Expert Workshop on Tropical Trawl Fishery Management 30th September - 4th October 2013, Phuket, Thailand.

Pauly, D. and Budimartono, V. 2015. Marine Fisheries Catches of Western, Central and Eastern Indonesia, 19502010- Working Paper \#2015 -61. Working Paper Series. Fisheries Centre. The University of British Columbia. 51 pp.

Pho, H. H. 2007. Fisheries development in Vietnam: a case study in the exclusive economic zone. Ocean and Coastal Management 50: 699-712. doi.org/10.1016/j.ocecoaman.2002.06.001

Pérez Roda, M.A., Gilman, E., Huntington, T., Kennelly, S.J., Suuronen, P., Chaloupka, M. and Medley, P. 2019. A third assessment of global marine fisheries discards. FAO Fisheries and Aquaculture Technical Paper No. 633. Rome, FAO. $78 \mathrm{pp}$.

Pitcher, T., Kalikoski, D., Pramod, G., and Short, K. 2009. Not honouring the code. Nature 457: 658-659. doi:10.1038/457658a.

Pomeroy, R.S. 1995. Community-based and co-management institutions for sustainable coastal fisheries management in Southeast Asia. Ocean \& Coastal Management 27: 143-162.

Pomeroy, R.S. 2012. Managing overcapacity in small-scale fisheries in Southeast Asia. Marine Policy 36: 520-527.

Pomeroy, R.S., Garces, L., Pido, M., and Silvestre, G. 2010. Ecosystem-based fisheries management in small-scale tropical marine fisheries: Emerging models of governance arrangements in the Philippines. Marine Policy 34: 298308.

Pomeroy, R., K. Hiew Wai Phang, K. Ramdass, J. Mohd Saad, P. Lokani, G. Mayo-Anda, E. Lorenzo, G. Manero, Z. Maguad, M. Pido, and G. Goby 2015. Moving towards an ecosystem approach to fisheries management in the Coral Triangle region. Marine Policy 51: 211-219.

Pomeroy, R., Parsk, J., Courtney, K., Mattich, N. 2016. Improving marine fisheries management in Southeast Asia: Results of a regional fisheries stakeholder analysis. Marine Policy 65: 20-29.

Purwanto 2010. The biological optimal level of the Arafura shrimp fishery. Indonesian Fisheries Research 16 (2): 79-90.

Purwanto, 2015. Biomass, fishing vessel productivity and potential production of demersal finfishes in the Arafura Sea. Journal Penelitian Perikanan Indonesia 21:187-199.

Ramiscal, R.V., Dickson, J.O., Salvador, N., Hilario, E.V. and Romero, R.O. 2017. Socio-economic study of trawl fisheries in Samar Sea, Philippines. Pp. 69 - 118. In: Socio-economics of trawl fisheries in Southeast Asia and Papua 
New Guinea (Siar, S. V., P. Suuronen, and R. Gregory, Eds.). FAO Fisheries and Aquaculture Proceedings No. 50. Rome, FAO.

Saikliang, P. 2013. Development, status and management of trawl fisheries in Thailand. Paper presented at the APFIC Regional Expert Workshop on Tropical Trawl Fishery Management 30th September - 4th October 2013, Phuket, Thailand.

Salayo, N.D., Ahmed, M., Garces, L., and Viswanathan, K. 2006. An Overview of Fisheries Conflicts in South and Southeast Asia: Recommendations, Challenges and Directions. NAGA, WorldFish Center Quarterly Vol 29 (1-2): 1120.

SEAFDEC 2003. Regional guidelines for responsible fisheries in Southeast Asia. Southeast Asian Fisheries Development Center (SEAFDEC). MRRDMD/SP/3. 56 p. ISBN:974-537-297-8.

Siar, S.V., Suuronen, P. \& Gregory, R. (Eds.) 2017. Socio-economics of trawl fisheries in Southeast Asia and Papua New Guinea. FAO Fisheries and Aquaculture Proceedings No. 50. Rome, Italy. 237 pp. http://www.fao.org/3/ai7812e.pdf

Silvestre, G., Federizon, R., Muñoz, J. \& Pauly, D. 1987. Over exploitation of the demersal resources of Manila Bay and adjacent areas. Papers presented at the 1987 IPFC technical symposium "Exploitation \& management of the marine fishery resources in SE Asia".

Silvestre, G., Garces, L., Stobutzki I, Luna C, Ahmed, M., Valmonte-Santos, R.A., Lachica-Alino, L., Munro, P., Christensen, V. \& Pauly, D. (eds) 2003. Assessment, Management and Future Directions for Coastal Fisheries in Asian Countries. WorldFish Center Conference Proceedings 67. WorldFish Center, Penang, Malaysia. 2003.

Squires, D., Ishak, O., Jeon, Y., Kirkley, J., Kuperan, K. and Susilowati, I. 2003. Excess capacity and sustainable development in Java Sea fisheries. Environment and Development Economics 8: 105-127.

Staples, D. and Funge-Smith, S. 2009. Ecosystem approach to fisheries and aquaculture: Implementing the FAO Code of Conduct for Responsible Fisheries. FAO Regional Office for Asia and the Pacific, Bangkok, Thailand. FAO RAP Publication 2009/11, 48 pp.

Stobutzki, I., Silvestre, G., and Garces, L., 2006a. Key issues in coastal fisheries in South and Southeast Asia, outcomes of a regional initiative. Fish.Res. 78: 109-118.

Stobutzki, I., Silvestre, G., Abu Talib, A., Krongprom, A., Supongpan, M., Khemakorn, P., Armada, N. and Garces, L.R. 2006b. Decline of demersal coastal fisheries resources in three developing Asian countries. Fish. Res. 78: 130142.

Sugiyama, S., Staples, D., and Funge-Smith, S.J. 2004. Status and potential of fisheries and aquaculture in Asia and the Pacific. FAO Regional Office for Asia and the Pacific. RAP Publication 2004/25. 53 pp.

Sumaila, R,U., Lam, V., Le Manach,F., Swartz,W. and Pauly, D. 2016. Global fisheries subsidies - An updated estimate. Marine Policy, DOI:10.1016/j.marpol.2015.12.026

Supongpan, M. and Boonchuwong, P. 2010. Bycatch management in trawl fisheries in the Gulf of Thailand. Thailand National Report. FAO-GEF REBYC-II CTI Project, 108 p. http://www.rebyc-cti.org/

Suuronen, P. and Gilman, E. 2020. Monitoring and managing fisheries discards: New technologies and approaches. Marine Policy 116. DOI: 10.1016/j.marpol.2019.103554

Suuronen, P., Chopin, F., Glass, C., Løkkeborg, S., Matsushita, Y., Queirolo, D., and Rihan, D. 2012. Low Impact and Fuel Efficient fishing - looking beyond the horizon. Fisheries Research 119-120: 135-146.

Suuronen, P., Gregory, R., Endryoyno, Imron, R.S., Dickson, J.O., Ramiscal, R.V., Liviko, I.M., Gisawa, L., Sanchang, S., Supongpan, M., Nhung, N.T.T., Anh, P.V. and Chanrachkij, I., 2013. Management of trawl fisheries in Southeast Asia and Coral Triangle region: the REBYC-II CTI Project. Fish for the People 11 (3): 21-24. Southeast Asian Fisheries Development Center (SEAFDEC).

Szuwalski, C.S., Burgess, M.G., Costello, C., and Gaines, S.D. 2017. High fishery catches through trophic cascades in China. Proc Natl Acad Sci USA (PNAS). 114(4): 717-721.

Teh, L. and Teh, L. 2014. Reconstructing the Marine Fisheries Catch of Peninsular Malaysia, Sarawak and Sabah, 1950-2010. Working Paper \#2014 -16. Working Paper Series. Fisheries Centre. The University of British Columbia. $20 \mathrm{pp}$. 
895 Teh, L., Zeller, D., and Pauly, D. 2015. Preliminary reconstruction of Thailand's fisheries catches: 1950-2010.

896 Working Paper \#2015 -01. Working Paper Series. Fisheries Centre. The University of British Columbia. 14 pp.

897 USAID Oceans 2020. Technical Guidance on the Design and Implementation of Electronic Catch Documentation

898 and Traceability (eCDT) Systems in Southeast Asia. The Oceans and Fisheries Partnership (USAID Oceans), 81 p.

899 https://www.seafdec-oceanspartnership.org/resource/technology-solutions-for-electronic-catch-documentation-

900 and-traceability-ecdt/

901 Willmann, R.B., Boonchuwong, P., and Piumsombum, S. 2003. Fisheries management costs in Thai marine fisheries. 902 In W.E. Schrank, R. Arnason and R. Hanneson (Eds.), The Cost of Fisheries Management, Burlington, Vermont: 903 Ashgate. 
Table 1. Estimated number and size of trawlers in the selected six SE Asian countries.

\begin{tabular}{|c|c|c|c|}
\hline Country & $\begin{array}{l}\text { Number of } \\
\text { trawlers }\end{array}$ & Size of trawlers & Remarks / Source \\
\hline Indonesia & $\begin{array}{c}\mathbf{5 7 0} \\
\text { (Arafura Sea } \\
\text { industrial trawler) } \\
\text { ca } \mathbf{1 3 0 0 0} \\
\text { (small-scale) }\end{array}$ & $\begin{array}{l}440 \text { fish trawlers; average } 263 \text { GT } \\
130 \text { shrimp trawlers; average } 153 \text { GT } \\
\text { Most vessels are } 2-5 \text { GT }\end{array}$ & $\begin{array}{l}\text { Licensed trawlers in } 2014 \text { (Directorate General } \\
\text { of Capture Fisheries). } \\
\text { The estimate is highly uncertain. Many of these } \\
\text { vessels are operating with trawl-like gears } \\
\text { because trawling has been banned. }\end{array}$ \\
\hline Malaysia & 6028 & $\begin{array}{rr}70 \text { trawlers } & <5 \mathrm{GT} \\
3999 \text { trawlers } & 5-40 \mathrm{GT} \\
1370 \text { trawlers } & 40-70 \mathrm{GT} \\
589 \text { trawlers } & >70 \mathrm{GT}\end{array}$ & $\begin{array}{l}\text { Licensed trawlers in } 2012 \text { (Malaysia } \\
\text { Department of Fisheries) }\end{array}$ \\
\hline Myanmar & 1240 & $\begin{array}{l}685 \text { trawlers }<24 \text { m (average } 82 \mathrm{GT} \text { ) } \\
555 \text { trawlers }>24 \text { m (average } 131 \mathrm{GT})\end{array}$ & $\begin{array}{l}\text { Licensed trawlers in } 2015 \text { (Department of } \\
\text { Fishery, Myanmar) }\end{array}$ \\
\hline Philippines & $\begin{array}{c}\text { 300-500 } \\
\text { (medium-scale) } \\
>\mathbf{2 0 0 0} \\
\text { (small-scale) }\end{array}$ & $\begin{array}{l}\text { Trawlers } 12-22 \mathrm{~m} \text { in length with } \\
\text { engine power of } 80-300 \mathrm{hp}(20-200 \\
\text { GT). } \\
\text { Small-scale municipal trawlers } \\
\text { (usually }<3 \mathrm{GT}, 5-12 \mathrm{~m}, 5-16 \mathrm{hp} \text { ) }\end{array}$ & $\begin{array}{l}\text { Based on the Bureau of Fisheries and Aquatic } \\
\text { Resources (BFAR) fisheries statistics in } 2015 \\
\text { and Ramiscal et al. (2017). Official statistics } \\
\text { include trawlers that are registered. } \\
\text { There is large uncertainty regarding the } \\
\text { number of municipal small-scale trawlers and } \\
\text { many of them are }>3 \text { GT. }\end{array}$ \\
\hline Thailand & 4087 & $\begin{array}{rr}225 \text { trawlers } & <5 \mathrm{GT} \\
304 \text { trawlers } & 5-10 \mathrm{GT} \\
517 \text { trawlers } & 10-20 \mathrm{GT} \\
1945 \text { trawlers } & 20-60 \mathrm{GT} \\
1096 \text { trawlers } & >60 \mathrm{GT}\end{array}$ & $\begin{array}{l}\text { Official statistic (DOF } 2015) \text {. Ca } 70 \% \text { of the } \\
\text { trawlers ( } 2800 \text { vessels) operate in the Gulf of } \\
\text { Thailand (GoT) and ca } 30 \% \text { in the Andaman } \\
\text { Sea. About } 20-25 \%(<1000) \text { of Thai trawlers are } \\
\text { pair trawlers. }\end{array}$ \\
\hline Vietnam & 20100 & $\begin{array}{ll}7750 \text { trawlers } & <90 \mathrm{hp} \\
2800 \text { trawlers } & <250 \mathrm{hp} \\
3950 \text { trawlers } & <400 \mathrm{hp} \\
5300 \text { trawlers } & <800 \mathrm{hp} \\
300 \text { trawlers } & >800 \mathrm{hp}\end{array}$ & $\begin{array}{l}\text { Based on official statistics of the Department } \\
\text { of Capture Fisheries and Resources Protection } \\
\text { in } 2015 \text {. Depending on the source, } 50-75 \% \text { of } \\
\text { all trawlers (10 000-15 } 000 \text { vessels) in Vietnam } \\
\text { are conducting pair trawling. }\end{array}$ \\
\hline In total & $\sim 47500$ & & $\begin{array}{l}\text { Ca } \mathbf{4 0} 000 \text { effective trawling units when pair } \\
\text { trawling units (c } 15000 \text { vessels) are counted as } \\
\text { one unit. C. } 30 \% \text { of the trawlers can be } \\
\text { categorized as small-scale }(<5 \mathrm{GT})\end{array}$ \\
\hline
\end{tabular}

Table 2. Average annual marine fisheries landings and estimated annual landings (tons) in trawl fishing in 2010-2016 in six SE Asian countries. Average annual shrimp landings in 2010-2016 reported to FAO are part of the estimated trawl fishing landings.

\begin{tabular}{|c|c|c|c|c|c|c|c|}
\hline & Indonesia & Malaysia & Myanmar & Philippines & Thailand & Vietnam & $\begin{array}{c}\text { Total annual } \\
\text { average }\end{array}$ \\
\hline $\begin{array}{l}\text { Average yearly landings in } \\
\text { 2010-2016 (FAO FishStat) }\end{array}$ & 6144840 & 1477638 & 1133093 & 2224240 & 1698879 & 2630198 & 15308834 \\
\hline $\begin{array}{l}\text { Estimated yearly landings } \\
\text { by trawling in 2010-2016 }\end{array}$ & 675000 & 665000 & 225486 & 224648 & 630284 & 1159914 & 3589332 \\
\hline $\begin{array}{l}\text { Estimated share (\%) of total } \\
\text { landings by trawl }\end{array}$ & 11.0 & 45.0 & 19.9 & 10.1 & 37.1 & 44.1 & 23.4 \\
\hline $\begin{array}{l}\text { Average yearly shrimp } \\
\text { landings in } 2010-2016 \\
\text { (tons) FAO FishStat }\end{array}$ & 255123 & 112404 & 27284 & 36137 & 42828 & 149986 & 623943 \\
\hline
\end{tabular}


Table 3. Summary of key barriers and challenges, and potential actions to solve the multitude of problems related to the management of trawl fishing in SE Asia.

\begin{tabular}{|c|c|c|}
\hline Barrier & Challenges & Guidance \\
\hline Overcapacity & $\begin{array}{l}\text { - High demand for fish } \\
\text { - Common property resources } \\
\text { - Inadequate capacity to control } \\
\text { fleet size } \\
\text { - Lack of alternative livelihoods } \\
\text { - Buy-back programs not affordable }\end{array}$ & $\begin{array}{l}\text { - Establish target capacity for each fleet } \\
\text { - Set effective caps on fleet size and power } \\
\text { - Strengthen vessel registration systems } \\
\text { - Prevent new entrances with effective license system } \\
\text { - Establish access rights when feasible } \\
\text { - Create realistic alternative employment opportunities } \\
\text { - Stimulate broad-based rural development }\end{array}$ \\
\hline Excessive effort & $\begin{array}{l}\text { - Weak control of overall effort } \\
\text { - No catch restrictions (no quotas) } \\
\text { - Fuel subsidies } \\
\text { - Lack of incentives } \\
\text { - Race to fish }\end{array}$ & $\begin{array}{l}\text { - Establish total allowable number of fishing days } \\
\text { - Establish annual seasonal closures (when feasible) } \\
\text { - Limit effort shift into other fishing types } \\
\text { - Create business drivers linked to sustainable practices } \\
\text { - Reform or remove the use of fuel subsidies } \\
\text { - Establish engine size and trawl headrope length caps }\end{array}$ \\
\hline $\begin{array}{l}\text { Poor } \\
\text { profitability }\end{array}$ & $\begin{array}{l}\text { - Low value of catch } \\
\text { - High operational costs } \\
\text { - Poor infrastructure } \\
\text { - Lack of capital to modernise } \\
\text { vessels and gears }\end{array}$ & $\begin{array}{l}\text { - Rebuild fish stocks (higher CPUE) } \\
\text { - Maximize fishing efficiency and minimize time at sea } \\
\text { - Increase value of catch (improve quality and processing) } \\
\text { - Reform fuel subsidies } \\
\text { - Promote better harvesting practices and infrastructure }\end{array}$ \\
\hline $\begin{array}{l}\text { Inadequate } \\
\text { zoning }\end{array}$ & $\begin{array}{l}\text { - Competition for fisheries resources } \\
\text { - Trawlers encroaching sensitive } \\
\text { shallow-water nursery grounds } \\
\text { - Skippers unaware of no-trawling } \\
\text { zones } \\
\text { - Weak monitoring and surveillance } \\
\text { systems } \\
\text { - Poor utilization of vessel } \\
\text { monitoring technologies }\end{array}$ & $\begin{array}{l}\text { - Identify vulnerable coastal areas (e.g. seagrass, corals) } \\
\text { - Establish effective trawl-exclusion zones } \\
\text { - Establish closures preferably in low-CPUE areas } \\
\text { - Establish effective surveillance and control systems } \\
\text { - VMS systems on vessels require activated } \\
\text { - Set physical anti-trawling barriers in sensitive grounds } \\
\text { - Use individual visual markings for all trawlers } \\
\text { - Promote a fishers' volunteer watch/reporting schemes } \\
\text { - Test allocated trawling areas }\end{array}$ \\
\hline $\begin{array}{l}\text { Extensive illegal } \\
\text { fishing }\end{array}$ & $\begin{array}{l}\text { - Large number of unlicensed } \\
\text { vessels } \\
\text { - Extensive lack of catch reporting } \\
\text { - Lack of effective monitoring } \\
\text { - Unclear legal frameworks } \\
\text { - Low risk of getting caught and } \\
\text { many loopholes } \\
\text { - Inadequate control of international } \\
\text { joint venture arrangements }\end{array}$ & $\begin{array}{l}\text { - Implement local action plans to combat illegal fishing } \\
\text { - Build local surveillance and enforcement capacity } \\
\text { - Utilize VMS and other technologies } \\
\text { - Establish compulsory catch reporting systems } \\
\text { - Close open access system to the extent possible } \\
\text { - Promote capacity building and training in inspection } \\
\text { - Promote inter-agency cooperation and consultations } \\
\text { - Implement penalties (forfeitures of gear and vessel) } \\
\text { - Prevent the marketing of illegal fish }\end{array}$ \\
\hline $\begin{array}{l}\text { Poor harvesting } \\
\text { pattern }\end{array}$ & $\begin{array}{l}\text { - Large amounts of juveniles caught } \\
\text { - Unlimited demand for fish biomass } \\
\text { - Bycatch of endangered species } \\
\text { - Serious conflicts with other fishing } \\
\text { sectors } \\
\text { - Sensitive habitats disturbed }\end{array}$ & $\begin{array}{l}\text { - Improve trawl selectivity step wisely } \\
\text { - Avoid areas of high density of juveniles and ETP species } \\
\text { - Develop positive business drivers linked to improved } \\
\text { fishing pattern (higher value of catch) } \\
\text { - Improve enforcement and set consequences that are } \\
\text { uniformly applied }\end{array}$ \\
\hline $\begin{array}{l}\text { Lack of trust } \\
\text { and co- } \\
\text { management }\end{array}$ & $\begin{array}{l}\text { - Lack of cohesive collaboration, } \\
\text { communication and participation } \\
\text { - Centralized top-down approach } \\
\text { - Conflicting goals and corruption } \\
\text { - Poverty pressure and insecurity } \\
\text { - No consensus on measures }\end{array}$ & $\begin{array}{l}\text { - Strengthen local authorities and fishers' associations } \\
\text { - Promote local leadership and co-management } \\
\text { - Establish transparent and frequent communication } \\
\text { among all key stakeholders } \\
\text { - Promote frequent stakeholder consultations and } \\
\text { participation in management planning }\end{array}$ \\
\hline
\end{tabular}




\begin{tabular}{|c|c|c|}
\hline & $\begin{array}{l}\text { - Lack of leadership at local level } \\
\text { - Complex cultural features } \\
\text { - Knowledge gaps }\end{array}$ & $\begin{array}{l}\text { - Build consensus and reduce knowledge gaps } \\
\text { - Secure fairness of management measures } \\
\text { - Ensure that all participants follow mutually agreed rules }\end{array}$ \\
\hline $\begin{array}{l}\text { Lack of user- } \\
\text { rights }\end{array}$ & $\begin{array}{l}\text { - Lack of ownership of resources } \\
\text { - Lack of motivation and interest } \\
\text { - Objectives and measures not } \\
\text { understood by key actors }\end{array}$ & $\begin{array}{l}\text { - Develop appropriate co-management arrangements } \\
\text { - Develop group fishing rights and territorial use rights } \\
\text { - Harness peer pressure to improve the compliance }\end{array}$ \\
\hline $\begin{array}{l}\text { Lack of scientific } \\
\text { knowledge }\end{array}$ & $\begin{array}{l}\text { - Status of stocks poorly known and } \\
\text { often contested } \\
\text { - Impacts of management measures } \\
\text { not known } \\
\text { - Declining scientific capacity and } \\
\text { lack of financial resources }\end{array}$ & $\begin{array}{l}\text { - Increase science-based information of status of stocks } \\
\text { - Increase evidence-based information on the potential } \\
\text { positive impact of fisheries management measures } \\
\text { - Strengthen fisheries log-book systems } \\
\text { - Build capacity and increase funding } \\
\text { - Promote education and build resilience }\end{array}$ \\
\hline $\begin{array}{l}\text { Inadequate } \\
\text { regulatory } \\
\text { frameworks }\end{array}$ & $\begin{array}{l}\text { - Political reluctance to make hard } \\
\text { management decisions } \\
\text { - Priorities on short-term goals } \\
\text { - Poor capacity and coordination } \\
\text { - Deficient legal and institutional } \\
\text { structures, complexity of systems } \\
\text { - Lack of continuity and priorities } \\
\text { - Unrealistic production targets }\end{array}$ & $\begin{array}{l}\text { - Build monitoring and enforcement capacity } \\
\text { - Clarify the key objectives of regulations; keep them } \\
\text { simple and workable } \\
\text { - Design management actions with key stakeholders } \\
\text { - Establish incentives for effective enforcement } \\
\text { - Promote training, demonstrations and new technology } \\
\text { - Improve the horizontal collaboration among various } \\
\text { policy makers, agencies and managers }\end{array}$ \\
\hline
\end{tabular}


920

921

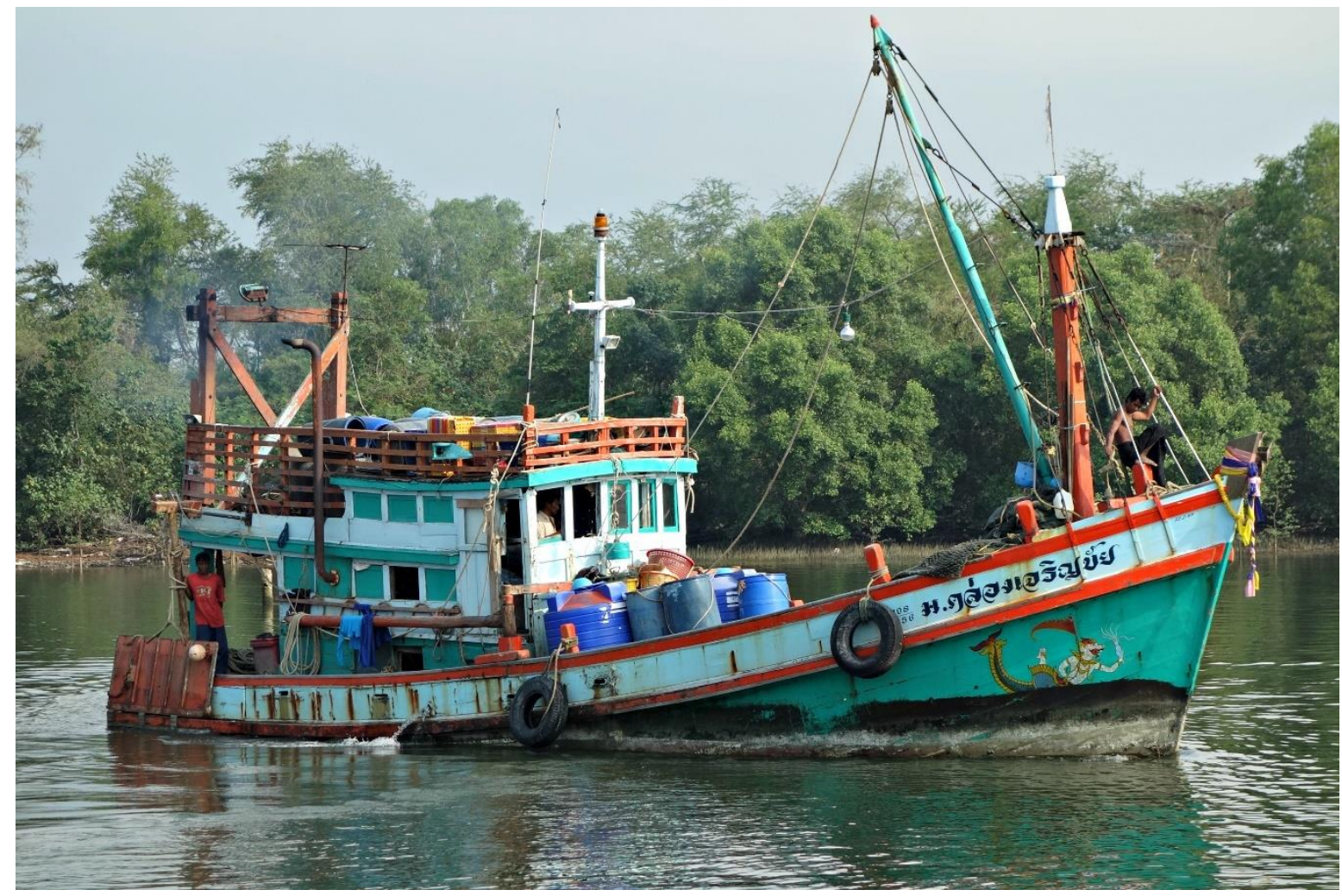

922 Figure 1. A typical medium-size Thai trawler (Photo: Petri Suuronen). 
The number of trawlers in the SE Asian region increased steadily from early 1960 s to early 2000s (Butcher 2004; Morgan and Staples 2006). After that the overall increase was modest and in some countries such as Thailand the numbers have decreased. The country-level data of trawling fleets, however, is highly uncertain. Various statistics and sources often show very different numbers. In some cases, the estimates are fraught with uncertainties of several orders of magnitude. The following paragraphs summarize the development of trawler fleets in six SE Asian countries included in this study.

Indonesia: Trawl fishing expanded in Indonesia in 1970s and negative impacts on fisheries resources were widely reported with serious user conflicts (Morgan and Staples 2006). Consequently, in 1980 a ban on industrial trawling was implemented in waters surrounding Indonesia except the Arafura Sea where industrial trawling was still permitted. However, the ban was never fully effective (Chong et al. 1987; Bailey 1997) and by 1990s there was an extensive resurgence of trawling, with many vessels operating illegally. By the late 1990s, the trawl ban had ceased to be effective (Butcher 2004; Morgan and Staples 2006; Purwanto 2010; Endryono 2017). The trawler fleet in Indonesia had a rapid growth in early 2000s. This was linked also to the opening of new fishing grounds (Anon. 2010). Due to the trawling ban many of the trawlers were not been registered as trawlers.

According to the official Indonesian Capture Fisheries Statistics (Ministry of Marine Affair and Fisheries, Directorate General of Capture Fisheries) the total number of trawlers in Indonesia in 2008 was 19558. Of these trawlers, 2745 were classified as double-rig shrimp trawlers, 4399 as stern shrimp trawlers and 12414 as finfish trawlers (Anon. 2010). Most of the larger trawlers operated in the Arafura Sea and Makassar Strait. Purwanto (2015) estimated that in 2011 there were 731 industrial shrimp trawlers (average 130 GT) in the Arafura Sea area with overall catch of 48370 tons of shrimp. Only 267 of these vessels, however, had a valid licence and their overall catch was about 17680 tons. Hence, most of the vessels were fishing illegally. Furthermore, in 2014 the trawler fleet in Indonesia had about 13000 smaller coastal trawlers operating trawls or trawl-like gears, and about 570 industrial trawlers that operated mainly in the Arafura Sea (official statistics). Endryono (2017) reported that 129 of the Arafura Sea industrial trawlers were shrimp trawlers while 440 vessels were demersal fishfish trawlers. Most of the shrimp trawlers were 60-200 GT and most of the finfish trawlers 100-300 GT. The length of the industrial trawlers was 35-45 m. In addition, in early 2010s there were about 22400 vessels in Indonesia that operated various types of bottom seines such as the cantrang-seine which is much like a Danish seine (Duto et al. 2013). The bottom seine fishing expanded after Indonesia in 1980 enforced the first trawling ban for vessels $>5$ GT. The adoption of seine fishing was a way to circumvent the trawling ban.

The Ministerial Regulation no. 2/2015 banned all types of fishing with trawls and seine nets in Indonesia effective January 1,2017 . This new ban resulted in gradual shrinkage especially of industrial shrimp trawling in Arafura Sea (Endroyono 2017). This has had major socio-economic impacts since Arafura Sea industrial shrimp trawling has contributed c. $45 \%$ of all shrimp catches in Indonesia. It is worth noting that the IUU fishing conducted by foreign vessels has been almost completely phased out in Indonesia under the new policy. This was accomplished with a tight at-sea control of fisheries (Endryono 2017; CEA 2018). The 2015 trawling ban has been the subject of intensive debate and has faced strong resistance by the trawl fishing sector. The implementation of the ban has been delayed in many coastal areas (CEA 2018). It is currently unclear how much trawl and seine fishing there is along the coast of Indonesia. The government of Indonesia has encouraged small-scale trawlers to replace trawl and trawl-like gear with other fishing gear through the gear-replacement program run by the Ministry of Fisheries.

Malaysia: The number of trawlers in Malaysia increased rapidly in 1970-1980s (Nuruddin and Isa 2013). Depending on the source and the year, trawl fishing contributes $45-48 \%$ of the total marine landings in Malaysia (Malaysia Department of Fisheries; Nuruddin and Isa 2013). In 2007 the licensed trawler fleet in Malaysia included 6340 vessels, 6116 vessels in 2011, and 6028 vessels in 2012 (Malaysia Department 
of Fisheries; Nuruddin and Isa 2013). The number of licensed trawlers is apparently slowly decreasing. Most of the trawlers are 5-40 GT but the number of trawlers of 40-70 GT is substantial. Although Malaysia has one of the best data collection and fisheries monitoring systems in SE Asia, not all trawlers operating in the Malaysian waters are registered and licensed (Teh and Teh 2014).

Myanmar: Myanmar had in 2015 c. 1240 licensed trawlers (Department of Fishery, Myanmar). In 2013 there were in total c. 1100 licensed trawlers (Aye and Win 2013) which indicates that the fleet has been growing. Almost $45 \%$ of these vessels were more than $24 \mathrm{~m}$ in length. The average size was $131 \mathrm{GT}$ and engine power $677 \mathrm{hp}$, reflecting a high fishing power. The trawlers less than $24 \mathrm{~m}$, however, also have a substantial fishing power with the average gross tonnage of 82 GT. Pair trawling is banned in Myanmar.

Philippines: The Philippines has a markedly smaller trawling sector than the other countries of this study. Most trawlers are municipal (coastal waters) vessels ( $<12 \mathrm{~m}$ in length, $<3 \mathrm{GT}, 10-16 \mathrm{hp}$ ). Many of these municipal trawlers, however, are not actually as small as the regulations require $(<3 \mathrm{GT})$. Many of them are markedly larger and are powered by $80-130 \mathrm{hp}$ engines, and hence should categorized as small-scale commercial trawlers or large municipal trawlers (Ramiscal et al. 2017). The total number of municipal trawlers is poorly known but obviously there are more than 2000 active vessels in the Philippines (Ramiscal et al. 2017). Municipal trawlers are targeting mainly shrimp in the shallow water coastal zone. In addition to the small-scale municipal trawlers, there is a commercial trawling fleet in the Philippines. The commercial fleet expanded in 1970s and early 1980s, and peaked in 1983 at 932 vessels (BFAR Fisheries Statistics; Ramiscal et al. 2017). The number of commercial trawlers has decreased during the last three decades due to the various trawling restrictions and increase of operation costs (Armada, 2004; Ramiscal et al. 2017). In 2015 there were 156 medium-scale (20-150 GT) and 338 smallscale (3-20 GT) commercial (licensed and registered) trawlers in the Philippines (Bureau of Fisheries and Aquatic Resources, Fishing Vessels Electronic Licensing System). There were no large-scale (>150 GT) trawlers in the vessel register. It is noteworthy that while the number of commercial trawlers has decreased, the number of Danish seiners has markedly increased in the Philippines. In 2007 there were 672 vessels conducting Danish seining (Ramiscal et al. 2017).

Thailand: In the early 1990s the total number of trawlers in Thailand peaked at around 13000 vessels, of which c. 10000 were demersal otter trawlers. Since then, the fleet has gradually been reduced (Supongpan and Boonchuwong 2010; Saikliang 2013; Noranarttragoon 2014; DOF 2015). In 2015, the total number of demersal trawlers was c. 4000 and of these vessel c. 1000 were conducting pair trawling (DOF 2015). The real number of trawlers is likely higher because not all trawlers in Thailand are registered and licensed (DOF 2015). Thailand is one of the few countries in SE Asia where the trawling fleet has been systematically reduced with the help of a strict license program. , The significant reduction of trawler fleet size is reflected in the total trawl catch which reduced by almost one order of magnitude from mid-2000s to mid-2010s.

The major part (c. 2500 vessels) of demersal trawlers in Thailand are $10-18 \mathrm{~m}$ in length with engine size typically of around 150 - $300 \mathrm{hp}$ and tonnage around 5-30 GT (Supongpan and Boonchuwong 2010; Eyars et al. 2017). An otter-board trawler in length class 14-18 $\mathrm{m}$ has an average tonnage of $27 \mathrm{GT}$. There is also a substantial number of trawlers in the $18-25 \mathrm{~m}$ length class (c. 500 vessels) with engine size of 150-500 hp and tonnage of around 20-80 GT (average $56 \mathrm{GT}$ ). Most pair trawlers are $18-25 \mathrm{~m}$ in length, have a tonnage of around $60 \mathrm{GT}$ and engine size of $60-550 \mathrm{hp}$. There are also some larger otterboard and pair trawlers (25-63 m, 60-300 GT, engine size up to $1700 \mathrm{hp}$ ) trawlers; these off-shore trawlers have mainly been used in the EEZs of the neighbouring countries through the bilateral arrangements. The Gulf of Thailand is the most important trawling area of Thailand and up to $85 \%$ of Thai trawl catches are taken there (Supongpan and Boonchuwong 2010). There are about 100 beam trawlers in Thailand; their share of the trawl catch is $0.1 \%$. 
Vietnam: The size of the trawler fleet in Vietnam is the largest of all the six countries included in this study. The overall number of trawlers in 2015-2016 was c. 20200 vessels (Department of Capture Fishery) but the size of the active fleet has fluctuated during the recent years. In 2010 the total number of trawlers was c. 19670 (Nguyen 2013) and in 2008 c. 24090 (Nguyen and Thi 2010). A significant part of the trawl fleet in Vietnam is conducting pair trawling. According to Nguyen and Thi (2010) in 2008 there were 16426 otter-board trawlers and 7665 pair trawlers (i.e., $32 \%$ of the total) in Vietnam. There are two types of pair trawling fisheries; one is targeting mainly pelagic species such as anchovies and is conducted with large trawls while the other is targeting mainly demersal species. Pair trawls are typically dragged along the seabed. Pair trawling is considered more cost-effective than single-boat trawling; this is mainly because a pair trawling unit can operate a bigger trawl in deeper waters and at higher speed than a single boat otter board trawler. Moreover, no energy is needed for dragging the trawl doors along the seabed. Shrimp/otter board trawlers have engine size of 20-400 hp and pair trawlers $90-800 \mathrm{hp}$. Most trawlers $<90 \mathrm{hp}$ target shrimp whereas trawlers $>90 \mathrm{hp}$ target finfish, squid and others (Nguyen 2013).

\section{Push-net fishing}

It is noteworthy that during the expansion of trawl fishing, a motorized push-net fishery also developed in many SE Asian countries and especially in Thailand (Silvestre et al. 1987; Nagalaksana 1987; DOF, 2015) and in some regions in the Philippines. The gear is pushed by a boat over the bottom in shallow waters, especially to catch shrimp. The net is fixed on crossed poles to keep it open. To ensure that the poles glide smoothly over the bottom, they are fitted with runners. The poles of small push-net boats are $6-15 \mathrm{~m}$ long but large push-netters use poles up to $44 \mathrm{~m}$. A census done in 1995 in Thailand counted about 4000 push-net boats (Butcher 2004). The census made in 2015 counted about 1500 push-netters (DOF 2015). Most ( $82 \%$ ) of these boats were relatively small ( $<10 \mathrm{GT}$ ) but there were also some boats larger than $60 \mathrm{GT}$. Hence, a significant number of push-netters are still operating in many areas in Thailand although the gear is banned. 
1054

1055

1056

1057

1058

1059

1060

1061

1062

1063

1064

1065

1066

1067

1068

1069

1070

1071

1072

1073

1074

1075

1076

1077

1078

1079

1080

1081

1082

1083

1084

1085

1086

1087

\section{Annex 2: Trawl operation in SE Asia}

Most trawling in SE Asia is single-net towing, i.e. the trawler tows only one trawl net. Multi-rig trawl arrangements (i.e., the trawler tows two or more trawl nets at the same time) are common in the Arafura Sea industrial shrimp fishery where double-rig trawls are used. Usually, no large bobbins or metal discs are attached to the ground-rope, but a chain and small rubber discs may be attached to it. Shrimp trawlers may use a tickler chain in front of the ground-rope. Uneven rocky bottoms are avoided because of high risk of gear damage.

The size of trawl gear depends on vessel size and power, fishing depth and target species. The headrope length of a typical bottom trawl towed by small- and medium-sized trawlers in SE Asia varies from $10 \mathrm{~m}$ to $25 \mathrm{~m}$ (Macfadyen et al. 2013; Eayrs et al. 2017; Siar et al. 2017). For the larger single-rig trawlers the headrope length is usually $25-35 \mathrm{~m}$ but can reach up to $50 \mathrm{~m}$. In double-rig industrial trawlers in Indonesia the headrope length of the trawls is usually $15-26 \mathrm{~m}$ (Gillet 2008), i.e. the individual trawls are smaller than in corresponding single-rig trawling. Pair trawls are in general larger than single-net trawls and have a significantly larger vertical opening (Nguyen 2017). Although pair trawlers may also target small pelagic fish, the trawl is usually towed on the seabed. Along with the trend of building larger trawlers there has been a tendency in SE Asia toward bigger trawls with increased headrope length and mouth opening (Gillet 2008; FAO 2014). In Malaysia the government has limited the length of the trawl headrope to a maximum of $40 \mathrm{~m}$ to prevent the growth of fishing pressure and to discourage the building of larger and more powerful trawlers. There are no studies that have assessed the effectiveness of this strategy.

The door spread (distance between trawl doors during towing) in single-net otter trawls is typically $30-$ $60 \mathrm{~m}$ in small-scale trawling, $60-90 \mathrm{~m}$ in medium scale trawling, and up to $150 \mathrm{~m}$ or even more in larger scale trawling. The wing-ends of the trawl net are connected to trawl doors by sweeps (bridles). A common length of sweeps in an average Thai trawler is 10-20 m (Eayrs et al. 2017) but sweeps can be markedly longer in larger fish trawls. In shrimp trawling it is a common practice to have very short sweeps, often only a few meters. Pair trawlers do not use trawl doors.

Towing speed in targeted shrimp trawling is typically $2.0-2.5$ knots and in mixed finfish-shrimp trawling 2.5 - 3.5 knots. In shallow-water small-scale shrimp trawling the towing speed may be only c. 1.5 knots. Pair trawlers can maintain higher towing speed than otter-board trawlers and are capable of catching faster-swimming species. 